\title{
Multi-approach mapping to help spatial planning and management of the kelp species $L$. digitata and $L$. hyperborea: Case study of the Molène Archipelago, Brittany
}

\author{
Bajjouk Touria ${ }^{1,}{ }^{*}$, Rochette Sebastien ${ }^{1}$, Laurans Martial ${ }^{1}$, Ehrhold Axel ${ }^{1}$, Hamdi Anouar ${ }^{2}$, \\ Le Niliot Philippe
}

${ }^{1}$ Inst Francais Rech Exploitat Mer, F-29280 Plouzane, France.

${ }^{2}$ Autoentrepreneur, F-65130 Taillade, Pere, France.

*Corresponding author : Touria Bajjouk, email address : touria.bajiouk@ifremer.fr

\begin{abstract}
:
The Molène Archipelago in Brittany (France) hosts one of the largest kelp forests in Europe. Beyond their recognized ecological importance as an essential habitat and food for a variety of marine species, kelp also contributes towards regional economies by means of the alginate industry. Thousands of tons of kelp are collected each year for the needs of the chemical and food industries. Kelp harvesting in Brittany mainly concerns two species, Laminaria digitata (59,000 t) and Laminaria hyperborea (24,000 t), that, together, represent approximately $95 \%$ of the national landings. Estimating the available standing stock and its distribution is a clear need for providing appropriate and sustainable management measures.
\end{abstract}

Prior to estimating the spatial distribution of biomasses, we produced a detailed seabed topography map with accurate hard substrate delineation thanks to surveys and appropriate processing of airborne optical and acoustic imaging. Habitat suitability models of presence-absence and biomass were then developed for each species by relating in situ observations from underwater video and sampling to the many biotic and abiotic factors that may govern kelp species distribution. Our statistical approach combining generalized additive models (GAM) in a delta approach also provided spatial uncertainty associated with each prediction to help management decisions.

This study confirmed that the adopted strategy, based on an integrated approach, enhanced knowledge on kelp biomass distributions in the Molène Archipelago and provided a promising direct link between research and management. Indeed, the high resolution topography and hard substrate maps produced for the study greatly improved knowledge on the sea bottom of the area. This was also of major importance for an accurate mapping of kelp distribution. The quality of the habitat suitability models was verified with fishing effort data (RECOPESCA program) and confirmed by local managers and kelp harvesters. Based on the biomass maps produced and their associated confidence intervals, we proposed more precise management rules than those already in use for both L. digitata and L. hyperborea. Our mapping approach is a first step towards sustainable kelp species management in the area. Introducing higher resolution environmental variables and population dynamics would help interannual management. 


\section{Highlights}

- Accurate maps of the topography and hard substrates were produced Zero-inflated biomass models based on presence-absence and biomass data from different sources were fitted with environmental data through Generalized Additive Models (GAM) for three Laminarian species. High resolution topography maps combined with the statistical models greatly increased knowledge on the laminarian biomass distribution and its confidence intervals in the Parc Marin d'Iroise (Brittany, France). This approach, directly linking researchers and managers, allowed for new resource management rules to be suggested.

Keywords: Laminaria, Lidar, Acoustic imagery, Zero-inflated model, Habitat mapping, Spatial management 
40 Kelp forests are some of the dominant producers and most diverse habitats within near-

41 shore coastal ecosystems (Mann 1973; Kerambrun 1984, Dayton et al. 1998). Beyond their 42 recognized ecological importance as an essential habitat and food for a variety of marine 43 invertebrates and fish species (Christie et al. 2003, Fowler-Walker and Connell 2002, Derrien 44 et al., 2013), they also contribute to regional economies for alginate industry. Used in many 45 applications such as pharmaceutical, cosmetic and food products, their industry records an 46 ever increasing demand (Frangoudes, 2012).

47 The Molène Archipelago (Brittany coast, France), located within the Parc Naturel Marin 48 d'Iroise (PNMI) marine protected area, hosts one of the largest kelp forests in Europe. It is 49 mainly structured by four species: Laminaria digitata, Laminaria hyperborea, Laminaria 50 ochroleuca and Saccorhiza polyschides. These kelp differ in their morphology, ecophysiology 
and longevity and show distinctive patterns of distribution on the shore (Birkett et al, 1998). L. digitata and L. hyperborea form the most extensive monospecific kelp beds. Tens of thousands tons of these two species are collected each year by a professional harvesting fleet (Arzel, 1998).

Management rules to access and exploit kelp have been developed over a long period along the coastal area of the French region of Brittany (Frangoudes, 2011). Even if L. digitata has been traditionally harvested for almost 170 years, the current rules were developed in the last 40 years when the fleet became mechanized. For L. hyperborea, some of the management rules come from the Norwegian experience (Vea and Ask, 2010).

Since 1985, Laminaria digitata production has been considered as quite stable in Brittany, even if some annual fluctuations are recorded (Laurans et al. 2010, Davoult et al. 2011). As to L. hyperborea, it is considered as a new harvest as its production only really started in 1996. Since 2007, the production has increased due to higher demands from the two main industrial firms and new vessels were able to target this kelp. The main part of the French seaweed harvesting activity takes place within the PNMI, mainly in the Molène Archipelago. Faced with this evolution and the prominent position of kelp in the coastal ecosystem off Brittany (Shaal, 2010; Leclerc, 2013), the need to increase overall knowledge has become a key issue in order to improve the management of the PNMI area. In fact, the spatial distribution of key species such as kelp (Derrien et al., 2013) at relevant scales is essential for coastal management and conservation of the environment (Hooper et al., 2005, Holmes et al. 2008). As a consequence, the ability to accurately quantify and map each of the main kelp species in this harvesting area is of upmost importance as exploiting pressure increases. Previous studies have estimated the Laminaria kelp stocks of the Molène Archipelago (Floc'h J.Y., 1967 ; Kerambrun, 1984, Piriou, 1987, Arzel, 1998), however the different methods used and the imprecise hard substrate localization conducted to varying stock evaluations and approximate estimations of distribution. In fact, various methods may be used for kelp forest characterisation (Kerambrun 1984, Ben Moussa 1987., Piriou, 1987, Bajjouk et al. 1996, Kepel, 1995), but there all have limitations to retrieve required information for kelp species standing stock estimation (Review Guillaumont et al. 1997): (i) traditional direct sampling methods such as video or diving are precise but time consuming and costly whatever the working scale of the study area, (ii) remote sensing tools, such as aerial photography or airborne and satellite imagery allow large area covering but rapidly reach their limits for subtidal surveys because of the absorption of visible radiation by water which limits this 
method to a the first ten meters when the maximum depth of observed kelp in this area is 30 m (Derrien, 2013), (iii) acoustic methods also allow large surface covering but may have a limited ability to discriminate between macrophyte types which leads to the difficulty of assessing biomass.

Statistical modeling approaches have a great potential for predicting distributions on large scale areas where field data are limited or unavailable (Guisan and Zimmermann, 2000). Several studies referring to the use of statistical models that link the effects of several biotic and abiotic factors to the distribution of kelp species have been published. Bekkby et al. (2009b) modelled the probability of observing four density classes of L. Hyperborea along the Norwegian coasts according to physical parameters using a generalized additive model (GAM). In Brittany, Méléder (2010) established a frequency of occurrence predictive map of kelp forest for the MESH project by applying a parametric linear regression model. The results were limited as shallow waters $(0-12 \mathrm{~m})$ were not sampled, coarse resolution maps of physical parameters that do not allow local effects to be assessed were used and important parameters, such as wave exposure, were missing. Bonetti (2009) continued this work using the same dataset while adding chlorophyll-a as an explanatory variable. Moreover, a crossvalidation technique was adopted to evaluate the performance of the spatial distribution model. This strategy allowed the use of all the observations made for the construction and validation of the model. More recently, Gorman et al. (2012) used the GAM method to model presence / absence and biomass of kelp forests in the Bay of Morlaix. L. digitata and $L$. hyperborea distributions were predicted on the basis of high-resolution maps $(25 \mathrm{~m}$ pixel size) which provided a level of information compatible with the needs of marine spatial planning.

Since kelp forests require hard substrate to live, statistical approach depends on accurate delineation of hard bottom area to produce distribution maps of good precision. The most accurate bottom substrate maps previously available were at a scale of 1:50000. Rocky areas may be provided from bottom topography expertise (2009a). But the finest available bathymetric digital terrain model (DTM) had a 100m resolution, which was too coarse knowing the high topographical complexity of the archipelago (Raffin, 2003). A precise bathymetry is also of particular interest for kelp forest delineation as it is of major importance in the calculation of bottom light availability, the main influential factor for photosynthetic species. For shallow waters, Lidar (Light Detection And Rangin) is quite an original approach to provide accurate DTM (Parrot et al., 2008). This has been successfully 
applied to coastal areas for ecosystem mapping (Lefsky et al., 2002; Chust et al., 2010), bathymetric programs (Irish and Lillycrop, 1999; Wozencraft and Lillycrop, 2003) and other geomorphological applications (Flood and Gutelius, 1997; Stock et al., 2005; Webster et al., 2006). Acoustic technology is commonly used in many seafloor mapping programs and marine monitoring habitat projects (Mitchell et Hughes 1994; Ehrhold et al, 2006, Cuadrado and Gomez, 2011; Legrand et al., 2012).

The present paper shows how different common and recent methods of observation can simultaneously be used to produce precise maps of kelp biomass for the sustainable spatially-explicit management of resources. The proposed approach consists in, at first, establishing surveys and appropriate processing methods in order to provide a detailed underwater topography of the area and to accurately delineate preferential hard substrates (bedrock) potentially colonized by kelp. Secondly, a habitat suitability model has been fitted

\section{Materials and methods}

\subsection{Study site}

The study area is the Archipelago of Molène located at the western tip of France in Brittany, in the Iroise Sea (Fig.1). The area is an extended plateau, which has a complex topography up to $50 \mathrm{~m}$ deep (at shelf break), has strong hydrological conditions (8 knots max.) and is often exposed to $\mathrm{W}$ and NE winds.

Separated from the Island of Ushant by a channel around 50 meters deep, the Molène Archipelago displays nine major islands and secondary islets (Guilcher 1959). These islands are the emerged part of a large rocky platform which extends over $150 \mathrm{~km}^{2}$. Apart from the islands of Molène and Béniguet which are $20 \mathrm{~m}$ and $16 \mathrm{~m}$ high respectively (Raffin, 2003), 
this Archipelago is composed of low-lying islands that do not rise more than ten meters above the level of high seas. This platform has many geomorphological features which have been shaped under the combined action of waves and currents.

Pierres Noires rocks are the southern edge of the Molène Archipelago. The relatively large area of foreshore and shallow waters ( 0 to 10 meters) is a remarkable element. This zone hosts especially vast boulder fields and rocks that are of particular importance for algal communities and ecosystems that depend on them.

\subsection{Optical and acoustic data acquisition}

Precise bathymetric and hard bottom maps were produced from (i) bathymetric and topographic Lidar acquisition and optical imagery provided by planes, particularly for intertidal areas, and (ii) acoustic imagery on board different scientific vessels, particularly for subtidal areas (Table 1, Fig. 2).

Lidar data were acquired in April/May 2010 by Blom Aerofilms for the PNMI using a Hawkeye II system. The planimetric accuracy is considered to be better than $280 \mathrm{~cm}$ with a confidence level of $95 \%$ and $50 \mathrm{~cm}$ for vertical accuracy. Simultaneously, spectral imagery was acquired with the sensor Asia Eagle 1k. More than 100 million Lidar topographic and bathymetric soundings were obtained. They were converted into the hydrographic vertical datum and Lambert 93 geodetic system using the ArcGIS software.

Acoustic data were issued from the Multibeam Echosounder (MBES) Simrad EM1000 that insonified the seafloor with at least $20 \%$ overlap in the echosounding corridors. This MBES operated at $100 \mathrm{kHz}$, and provided multibeam bathymetry with vertical resolution better than $0.5 \%$ of water dept. Other acoustic data were issued from the GeoSwath interferometer. This system provides compact and robust system which is suitable for deployment in shallow waters, an area where towed sidescan sonar has particular problems. A full description of used acoustic system and data preprocessing is given by Le gall et al. (2014).

Resulting bathymetric data were converted to chart datum based on the semi-diurnal tides measured at Le Conquet pier. Nearly 190 million points were gathered from three surveys of acoustic measurements preprocessed using SonarScope software (CIfremer). 
180

181

182

183

Variables governing the distribution of marine benthic habitats have been widely discussed within the framework of the European mapping projects MESH (Connor, 2005) and EUSeaMap (Cameron \& Askew, 2011). All spatially available environmental data having a known or supposed influence on kelp forest distribution were gathered to allow statistical model testing (see appendix). Oceanographic variables were retrieved from the PREVIMER project (Lecornu et De Roeck, 2009). Data originated from averages of 6 years (2006-2011) hind-cast archives (recorded hourly) for the variables resulting from the MARS3D hydrodynamical model and had a $250 \mathrm{~m}$ regular grid resolution. Data were averages from the 2009 - 2011 period when issued from the WaveWatch wave model which had a non-regular grid, more precise along the coasts (Ardhuin, 2012). Light data were derived from MERIS satellite images averaged from the 2007-2009 period (Saulquin et al., 2010). Variables derived from the bathymetry were based on a high resolution $(5 \mathrm{~m})$ DTM produced for the study.

\subsection{Kelp sampling}

The sampling plan (Fig. 2) was designed to encompass the broader range of predictor values and to minimize the effort required in terms of logistics and navigation constraints. Caution was taken to avoid sampling areas where kelp commercial harvesting had been recorded.

\subsubsection{Video sampling}

Information on the presence/absence of Laminaria species was acquired by high definition video towed in a cage directly underneath the ship (Segalen system 2010). Video data processing was performed using the COVER software "Customizable Observation Video imagE Record" (developed by Ifremer for Coralfish project) allowing to produce a table of geo-referenced observations. Presence or absence of kelp, all species combined, was reported at regular automatic distance intervals. As video observations did not allow for species identification, data were mainly used to detect absence and thus the limits of species distribution. Twenty three video profiles were recorded across the study area.

\subsubsection{Biomass sampling}

For each station, species-specific density and biomass were recorded in three replicates of $1 \mathrm{~m}^{2}$ quadrats considered homogeneous and representative of the surrounding area. Stations were sampled at low tide for the intertidal areas and by scuba diving for the subtidal areas in order to sample all kelp species depth zones. Removed kelp were sorted by species and 
weighed separately. One hundred and thirty five stations were sampled across the study area.

\subsubsection{Proximity to sediment impact evaluation}

Proximity to sediment seems to be an element which could impact the local dynamic of kelp (Derrien, 2013; Gorman et al. 2012). In order to evaluate this potentiel impact, a specific protocol has been established. On two transects, three $1 \mathrm{~m}^{2}$ quadrats were positioned at three locations: 4, 15 and 30 meters away from the sediment boundary, respectively at 18 , $15,12 \mathrm{~m}$ depth. We assumed that the impact increases when a sample is closer to the sediment. Size structure and biomass of kelp were recorded on these six square meters. As the characteristics of the study area did not allow to have whole transects at a unique depth, 3 additional replicates were sampled at $18 \mathrm{~m}$ depth on a rocky outcrop far from the influence of sediment. The latter were used as a reference to exclude depth influence.

\subsection{Harvesting data}

Faced with a lack of data to precisely assess the spatial distribution of harvest and fishing effort, Ifremer has implemented, since 2005, the Recopesca project. It consists in fitting out sensors which record data on fishing effort to voluntary fishing vessels. The challenge was to develop different sensors which didn't cause trouble to the fishermen (Leblond et al., 2008). Electronic devices which monitor the position of the vessel were installed on board and automatically stored the data in what is called a "concentrator" and sent it to Ifremer databases by GPRS every 24 hours. This system is equivalent to the Vessel Monitoring System (VMS) although here it equipped smaller vessels, from 6 to 12 meters.

With the position of the vessels, the data were analysed to implement the spatial distribution of effort and production for each vessel outing (Leblond et al., 2008). In the kelp fleet, one position per minute was recorded. The harvesting activity was taken into account when the average speed was inferior to 1 knot when targeting L.digitata and 2.5 knots when targeting L. hyperborea. From this analysis, two types of representation could be developed: the first one showed only the harvesting positions of the vessels and the second aggregates the fishing activities (effort or harvesting) on a specific 1 minute grid. The harvesting per boat is divided into in each cell proportionally to the estimated fishing time.

\subsection{High resolution bathymetric and substrate mapping}

\subsubsection{Seabed topography mapping}


Lidar and acoustic data were merged to provide a unique georeferenced digital elevation model of the Molène Archipelago.

The bathymetric map with a resolution of $5 \times 5 \mathrm{~m}$ was obtained by ordinary Kriging the billion points data using Isatis Geostatistical software. A variogram was fitted with a linear model that had a $50 \mathrm{~m}$ radius neighborhood. The neighborhood was divided into eight octants with an optimum number of samples of 3 per octant to avoid taking into account the points of the same transect. The maximum number of consecutive empty sectors was 3 and the minimum number of points required for interpolation was 2 to limit border area extrapolation. The quality of the resulting model was controlled by graphical visualization of the results through isolines that enabled to clearly identify potential interpolation artifacts.

\subsubsection{Hard substrate mapping}

The method used to delineate areas of rocky substrates was performed using GIS to 1:2000 based on acoustic and optical data (Fig. 3).

For littoral and shallow water areas, aerial images acquired during the Lidar surveys were used to delineate the bedrock where the seabed was visible (Fig. 3b). Where not visible, DTM derivatives, such as hillshade and slope were used. Their signatures help differentiate soft bottom from hard substrate: (i) irregular contours highlighted by hillshade (Fig. $3 \mathrm{c}$ ) indicate rocky bottoms while soft and rounded up appearance generally denoted sand accumulations. (ii) Rapid transitions from steep sectors to gentle slopes generally indicated the boundary between soft and hard bottoms.

In subtidal areas, hard substrate was mainly delineated using acoustic images (Fig. 3a) that consisted in mosaics of sonar geoacoustic reflectivity in the shallow waters and Klein sonar reflectivity in deeper areas. The range of sonar signatures was very large and individualized, allowing to accurately separate rocky hard bottoms from soft bottoms with sediment, often shaped by currents.

\subsection{Kelp species predictive biomass mapping}

\subsubsection{Outlines of the method}

For kelp mapping and stock estimating, statistical models of presence / absence and biomass were developed for each species separately by relating in situ underwater video observations and samples to available environmental factors that may govern kelp species distribution. Figure 4 shows the modeling process used for kelp forest mapping. The modelling process relied on the method developed by Gorman et al. (2012) in the Bay of Morlaix: (i) in situ 
observations (presence/absence and biomass) were cross-tabulated with all available environmental factors, (ii) correlated environmental variables were separated in the models tested, (iii) a model selection procedure allowed to choose the best model for each species and (iv) models were used to map the probability of species presence and biomass. This method was improved through different steps: (i) physico-chemical parameters were integrated, (ii) a cross-validation approach allowed to choose the best models for their robustness of prediction, (iii) the species spatialized total biomass was estimated with a delta model combining a presence/absence model to a biomass where kelp presence is predicted (iv) uncertainty of prediction was estimated providing complementary mapping products (minimum and maximum) that may help management decisions. All statistical operations were achieved using the R software.

\section{Predictor correlation tests}

For identifiability problems, highly correlated environmental variables were not included in the same models. Correlations between all possible pairs of variables were tested using the Pearson rank coefficient. All pairs with a Pearson coefficient value exceeding 0.7 were considered as correlated. This step also allowed to reduce the number of models to be tested.

\section{Statistical model selection with a cross-validation approach}

Kelp biological response (presence/absence or biomass) was estimated using Generalised Additive Models (GAM), a semi-parametric extension of Generalised Linear Models (GLM, see Guisan et al, 2002 and Wood, 2006). This type of model offers a great flexibility in the shape of the response curve. Indeed, the response of organisms to their environment rarely results in a linear relationship, especially when working on large scale areas that induce greater physical and environmental parameter variability. GAM models were fitted with the mgcv package in the R-software (Wood, 2011).

Total biomass distribution estimations were based on a delta approach (Stefanson, 1996; Rochette et al., 2010). This consisted in building two separate sub-models: a presenceabsence (P/A) sub-model and a biomass sub-model. Specific data used and model construction for these two sub-models are detailed further.

The cross-validation approach used for both sub-models was similar. Models were fitted using $75 \%$ of the data. Predictions were made for the remaining $25 \%$ and were compared with observed data. This cross-validation was repeated 100 times with random data re- 
sampling. The random data re-sampling respected the total proportion between presence and absence for the P/A sub-model. The 100 times repetition was considered sufficient to reach result convergence. For each of the 100 cross-validations, models were ranked from best to worst based on a percentage of error on the validation dataset, specific for each submodel (detailed below). Models were ranked again considering the median of the 100 ranks. The model which displayed the best median of the 100 rank was considered to be the best one. Models which had the best medians and had a 100 rank distribution and were not significantly different from the best model were considered as having the same quality of prediction; they could not be statistically differentiated. This cross-validation method was performed iteratively : (i) models were fitted against one environmental variable, (ii) environmental variables with the statistically best quality of prediction were kept as possible first parameters, (iii) models were fitted against two variables, the first one being one of those kept at the first step, (iv) the procedure was repeated until the models got 5 environmental parameters. Interactions of order two were also tested at each iteration. This iterative procedure limited the number of model configurations tested, which could be huge knowing the number of environmental variables available. All models kept at the different iterations were finally ranked with the median of their 100 ranks. This was allowed because the 100 random data subsamples were the same for each model tested. The best model amongst all was retained for prediction. If distinction could not be made statistically among ranks of the best models, priority was given to models with physical parameters that have more biological sense with regards to kelp species. Indeed, structure difference between best models was often due to two correlated physical parameters of the presence interactions with a spatially limited significance, thus providing equivalent prediction maps. For instance, the model "Biomass Bathymetry + Factor1" can have the same quality of prediction as the model "Biomass Light + Factor1" as bathymetry and bottom light availability are highly correlated parameters. In this case, the model displaying light was preferably chosen because light has a direct effect on the species physiology. Bathymetry has only an indirect effect, in particular through light availability.

\section{Building biological response prediction maps}

The best model selected predicted the response variable as a function of all possible combinations from the values of the selected environmental variables. Each pixel of $5 \mathrm{~m} \times 5 \mathrm{~m}$ (finest resolution of environmental variables) contained a unique combination of values of each environmental variable, which could have its own prediction through the model. 
A final prediction map of the response variable was obtained by applying a mask on nonrocky areas, on which kelp could not be present. Caution was taken on the interpretation of predictions when environmental variables were outside of the range encountered in the in situ data to avoid uncontrolled and potentially meaningless extrapolations.

\section{Mapping statistical indicators of prediction}

It should be noted that predictions were not a single mean but a probability distribution around a mean (distribution of possible values for each pixel). Each prediction was performed with a statistical confidence interval based on the assumption that the estimation error of a parameter follows asymptotically a normal distribution when the number of observations tends to infinity. These confidence intervals were used to produce different indicators to map minimum and maximum predicted distributions with $5 \%$ and $95 \%$ quantiles. Moreover, rather than the mean, medians were used as the best predictions. Although estimators uncertainty may be Gaussian, the resulting predicted probability distributions were not and the median was the closest to the most probable value. The median may also be considered as a $50 \%$ risk of underestimation, which is a good indicator for management approaches.

\subsubsection{Presence/absence sub-model}

The presence-absence sub-models were fitted using all adequate in situ observations. For video data, only absence samples were used as video did not allow species identification. Data from in situ diving and low tide measurements were rather presence data, which balanced absence video data.

Spatial proximity of samples, in particular data issued from video sampling, may conduct to parameter over-estimation due to spatial auto-correlation. To reduce problems of autocorrelation, a grid method was used (Keil et al, 2013). Correlation was estimated between the response variables for different classes of distances. A minimum of $50 \mathrm{~m}$ between observations was a good compromise between auto-correlation and the amount of data remaining to fit the models. The study area was divided into $50 * 50 \mathrm{~m}$ grid cells. The average position of samples in each cell was retained as the unique sample of the grid cell. If any observation was a presence, the sample was considered as a presence.

The GAMs were built with a binomial distribution with a logit link function. The effect of predictors was fitted with a smooth function $(s)$ on the individual effects and tensor "te" for interactions (Wood, 2006). The maximum smoothing parameters of the functions were set so 
that it was equivalent to a polynomial of degree 3 , a parsimonious approach to allow biological interpretation.

Since the model predicts a probability of presence, a threshold value was required to determine if the probability was rather an absence or a presence. The intuitive threshold value is 0.5 . However, an unbalanced sampling design between observations of presence and absence in relation to selected physical parameters requires a revised threshold. This threshold was chosen following the cross-validation method. For each of the 100 crossvalidations, the threshold value leading to the smallest prediction error on the validation sub-dataset was retained. The mean of the 100 threshold values, named "BestTHD", was the best compromise for predicting presence / absence.

The model selection during the cross-validation process required an index of the quality of prediction adapted to binomial models. The area under the curve (AUC) approach is commonly used to assess the quality of binomial models (Elith et al,, 2006; Townsend Peterson et al., 2008). Here, the AUC value was calculated on the validation sub-dataset for each of the 100 iterations of the cross-validation. The higher the AUC, the better the fitting quality of the model. The AUC value was used to rank the models in the iterative crossvalidation procedure.

\subsubsection{Presence-only biomass sub-model}

This sub-model only applies to presence-only data. Species-specific biomasses from in situ diving and low tide measurements were used. The three replicates for each station were averaged. The sampling plan designed for presence-only data did not require specific attention on spatial auto-correlation. In addition to the test on the number of variables, different distributions of residual formulations were tested: Gaussian, log-normal and Gamma distributions. The last two prevent negative predictions and allow for non-rare high values.

The model selection during the cross-validation process required an index of the prediction quality fit for the estimation of biomass. A coefficient of variation (CV) estimated the relative percentage of error between predictions and observations on the validation dataset: The lowest the $\mathrm{CV}$, the better the fitting quality of the model. The CV value was used to rank the models in the iterative cross-validation procedure.

\subsubsection{Combination of presence/absence and biomass sub-models} best model of presence/absence and the best model of presence-only biomass. Variables 
selected in sub-models may be different as kelp presence and biomass are not necessarily governed by the same environmental conditions.

The prediction of biomass was produced with a simple multiplication of the probability of presence with the prediction of the presence-only biomass. Estimation of uncertainty in delta models may be tricky when both distributions are not Gaussian. To allow for this estimation, a resampling approach was used. For each pixel, 5000 values were randomly resampled in the distribution of the Gaussian error around the prediction in the logit scale for the P/A model. The 5000 values were transformed with the logit ${ }^{-1}$ function to be in the scale of the probability of presence. In parallel, for each pixel, 5000 values were randomly resampled in the Gaussian error distribution of the biomass presence-only prediction. The 5000 values of the two distributions were multiplied together to obtain the 5000 -values distribution final biomass prediction for each pixel. Quantiles 5\%, 50\% and 95\% were extracted for each pixel to map estimations of the minimum, the median and the maximum biomass predictions. The map of medians remained the best estimation of biomass in the study area. The uncertainty of prediction may be approached through the $5 \%$ and $95 \%$ biomass maps. The presence-only biomass sub-models selected used Gamma or log-normal distributions that allowed a non-negligible number of high predictions, exacerbated by the relatively high uncertainty of prediction due to the small sample size. For some pixels, excessive predicted biomass that had no reality in the field was predicted. To avoid excessive stock estimates, predictions were truncated to $10 \%$ above the maximum observed biomass prediction. Although truncated, the total estimated biomass may be slightly overestimated, especially for the maximum biomass maps, as the uncertainty of prediction was particularly high in some areas.

The final maps were also limited in space according to three conditions: (i) where the probability of presence was lower than $\mathrm{Th}_{\mathrm{p}}=5 \%$, the risk was estimated to be small enough to predict total absence of kelp. These low probability areas were generally associated to particularly high uncertainty on presence-only biomass predictions leading to unlikely biomass predictions. The $5 \%$ limit based only on the P/A sub-model avoided unlikely predictions. (ii) Predictions in areas where bathymetry was greater than the maximum bathymetry where kelp were observed, $T h_{b}=30 m$, were assumed empty of kelp. (iii) Areas outside the rocks delineated in the present study were considered empty of kelp. 


\section{Results}

\subsection{Topography and hard substrate mapping}

Several bathymetric surveys covered the entire Molène site. Figure 5a illustrates the DTM (Digital Terrain Model) that was obtained with a resolution of $5 \mathrm{~m}$. The maximum depth recorded was $89 \mathrm{~m}$. The interpretation of the imagery, DTM and derivates enabled to accurately identify two seabed classes: hard substrates, including massive rocks and boulders and homogeneous sediment units. These hard substrate, potentially allowing for kelp development, represented more than $60 \%$ of the bottom of the study area. Results obtained showed an uneven distribution (Fig. 5b). The main outcrops of hard substrate occupy the southern fringe of the Archipelago extending well beyond a depth of $30 \mathrm{~m}$. In the north hard substrate is often intertwined with soft sediments.

\subsection{Kelp forest species distribution}

Predictions resulted in $5 \mathrm{~m}$ resolution grid maps showing the probability of the presence of kelp species or its biomass in each grid cell. The analyses showed that among environmental variables tested, only some of them were useful for predicting kelp forest distribution depending on the species and predicted attributes.

\section{L. digitata}

Presence-absence of $L$. digitata distribution was best determined by combined effects of depth, sediment proximity along current direction, benthic position index (BPI), immersion rate and spring temperature (Table 2 ). The model explained $75.3 \%$ of the deviance in presence and absence of observations. Assessing the predictions by the cross-validation method revealed high prediction accuracy (area under the curve, AUC $=0.88$ ). Depth, as well as its interaction with the $\mathrm{BPI}$, sediment proximity and interaction temperature and immersion were the most important contributors for predicting the presence of L. digitata.

Biomass observations showed an average of $6.7 \mathrm{~kg} / \mathrm{m}^{2}$ for L. digitata. Its variability throughout the study site should be pointed out with a relatively high standard deviation of $5.1 \mathrm{~kg} / \mathrm{m}^{2}$. The sub-model for biomass of $L$. digitata where present, was predicted using the additive contributions of principally light (55.62) and its interactions with wave exposure and winter temperature. Total suspended matter contributed little and only through the interaction with light (Table 3). The selected model explained $83.49 \%$ of the deviance. The cross-validation method showed a coefficient of variation of $78.11 \%$.

Results also showed that although some of the environmental factors, such as temperature, had a coarse resolution, their integration to the statistical model contributed nevertheless significantly to describe $L$. digitata distribution.

Only median maps are presented even if the extreme limits (minimum and maximum) of the predicted values were also produced. L.digitata distribution appeared to be limited to the intertidal zone around the islands and to very shallow waters (Fig. 6ab). This was confirmed 
by summing up the biomass according to bathymetric classes which showed that most of the L. digitata standing stock was located between 0 and 3 meters (Fig $6 \mathrm{c}$ ).

474

475

Laminaria digitata forests cover was estimated at 4686 ha using a best estimated threshold value of $T h_{p}=0.45$ with a minimum and maximum occupied area being respectively 4050 and 5770 ha. As to biomass, the median standing stock of L. digitata within the Molène Archipelago was estimated at $98401 \mathrm{t}$, with a minimum and a maximum, respectively, of 53 $374 \mathrm{t}$ and $164851 \mathrm{t}$.

The harvesting area obtained by processed RECOPESCA VMS data showed that the harvesting activity takes place mainly in the northern part of the Molène Archipelago (Fig 6 d) and limits fit well with the estimated distribution from our model.

\section{L. hyperborea}

The best model that explained $78.89 \%$ of deviance for the presence of L. hyperborea included depth, winter temperature, sediment proximity along current direction and benthic position index (Table 4). The cross-validation method showed an AUC of 0.96. Depth and its interaction with sediment proximity displayed the highest contribution to the presence of $\mathrm{L}$. hyperborea with respectively $33.87 \%$ and $26.84 \%$.

Using a best estimated threshold value of 0.65 , the surface area occupied by L. hyperborea was estimated to be 11052 ha, with a confidence interval ranging from 10404 to 11533 ha. Its median standing stock within the Molène Archipelago was estimated at $426518 \mathrm{t}$, with a minimum and a maximum, respectively, of $260527 \mathrm{t}$ and $669044 \mathrm{t}$.

Biomass observations showed an average of $5.8 \mathrm{~kg} / \mathrm{m}^{2}$ for L. hyperborea. As for L. digitata, the variability of observed biomass presented a relatively high standard deviation of 4.5 $\mathrm{kg} / \mathrm{m}^{2}$. Biomass where L. hyperborea was present was mainly modeled by the same predictors as presence/absence. The selected model explained $79.59 \%$ of the L. hyperborea biomass deviance (Table 5). A cross-validation showed a CV (Coefficient of Variance) of $57.55 \%$. Sediment proximity as well as its interaction with depth were one of the most important contributors for predicting L. hyperborea biomass. This result seems to be in line with in situ observations that highlight sand scouring as a significant factor limiting the development and growth of kelp species.

Figure 7 shows the results obtained from measurements of sediment proximity impact evaluation. The size structure of individuals was expressed as the relationship between frequency and stipe length classes according to distance from the sediment. 
Indeed, the lowest stipe size was recorded in sediment samples (quadrats 5 and 6) that received the strongest effect of sand scouring and was 60 to $70 \mathrm{~cm}$ in length, while further away from the impact of the sediment (quadrats 1 and2) a longer stipe size was observed (more than $120 \mathrm{~cm}$ ). For samples at the same bathymetry away from the sediment the size structure was different with several higher individuals. These elements reinforce the possible scouring effect on one part of the population located close to sand, not to forget the role played by swell and currents.

Unlike L. digitata, distribution of L. hyperborea was much broader (Fig. 8ab) and seemed to be present in deeper areas. The maximum recorded depth for the in situ presence of this species was around $29 \mathrm{~m}$. According to the bathymetric gradient, the estimated standing stock distribution showed that biomass increased with depth from $23000 \mathrm{t}$ at 0 to $3 \mathrm{~m}$ to reach the maximum available stock (225 $231 \mathrm{t}$ ) in areas located between 7 to $15 \mathrm{~m}$ and become negligible beyond $30 \mathrm{~m}$ (Fig8 c). As shown on figure 8d the zoning currently used by the profession for fallow exploitation of this species, is large and do not appear to be appropriate when considering the distribution of L. hyperborea biomass.

\section{S. polyschides}

Occurrence of S. polyschides distribution was modeled by combined effects of principally light and sediment proximity along wave direction associated with current and wave exposure (Table 6). The model explained $51.73 \%$ of the deviance in the presence and absence model. Assessing the predictions by the cross-validation method indicated high prediction accuracy with an area under the AUC curve of 0.89 . The fraction of the light reaching the sea bottom and distance to sediment due to wave exposure were retained as factors that mostly explained the distribution of S. polyschides with a contribution of respectively $20 \%$ and $17 \%$. Nevertheless, the high residuals (non explained deviance) of $48.27 \%$ was approximately twice the value of those of the Archipelago's main species, $L$. digitata (24.17\%) and L. hyperborea (21.11\%).

When compared to L. digitata and L. hyperborea distributions, S. polyschides was modeled present in an intermediate zone between these two species (Fig. 9).

The use of threshold values $\left(\mathrm{Th}_{\mathrm{p}}>=0.45\right.$ for L. digitata, $>=0.65$ for $L$. hyperborea and $>=0.48$ for S. polyschides) from occurrence probabilities, enabled to delineate between presence and absence areas for the 3 kelp species. Comparing the presence areas to the bathymetry allowed to determine their vertical zonation, as light and bathymetry were the main parameters determining kelp species presence. L. digitata was predicted to be mainly located 
between 2 and $-6 \mathrm{~m}$, L. hyperborea between 0 and $-19 \mathrm{~m}$ and S. polyschides between 2 and $10 \mathrm{~m}$ (Fig. 10). S. polyschides seemed to be able to extend over L. digitata and L. hyperborea areas but shallower than the latter.

\section{Discussion}

\subsubsection{Hard substrate mapping}

Visual comparison of the substrate digital map produced with the existing map showed that with a scale of 1:2000, overall knowledge has been largely improved by our study giving a more detailed interpretation of the limits of the hard substrate. In particular, we showed that certain rocky areas were less continuous than supposed in the northern part of the Molène Archipelago and also underestimated on the western side. This demonstrates the interest there is to update this information as a key variable used for limiting the model prediction area to this kelp forest preferential habitat. The adopted strategy, based on optical airborne acquisitions in shallow areas completed by acoustic data in deeper areas where optical signals cannot be recorded because of light penetration limitation, has also proved its effectiveness in producing a continuous hard substrate layer for the entire study site. Whether for bathymetry or the substrate, newly obtained resolutions were in fact much more relevant to characterize the distribution of kelp habitat than previously existing data.

\subsubsection{Main physical predictors driving kelp species distribution}

Our study showed that the main kelp species do not respond in the same way to predictor variables. Some of the selected variables behave as strong habitat drivers while others present a minor effect in shaping kelp distribution. Factors that influence their distribution also differ depending on the model, presence/absence or biomass prediction.

Bathymetry - Bathymetry appeared to play a major role for $L$. digitata as well as for $L$. hyperborea distributions. This is consistent with the results of other studies showing its significant impact (Bekkby et al., 2009b; Meleder et al., 2010; Gorman et al., 2012). Depth limits for presence/absence also agree with those found in the literature. In Europe, the maximum depth for kelp presence is generally around 35m (Birkett et al, 1998). Derrien et. al. (2013) have shown that depth limits for kelp in Brittany significantly decreased with turbidity and varied from $-32.2 \mathrm{~m}$ in offshore clear water to $-1.6 \mathrm{~m}$ in sheltered and turbid sites. Depth does not have a direct impact on kelp distribution, but it reflects light attenuation. The probability of finding kelp increases as the light exposure index increases (Lobban and Harrison 1994 , Bekkby 2009 b), with a high quantitative light demand for S. polyschides (Norton \& Burrows, 1969a in Werner) in accordance with the highest contribution of this parameter to the probability of occurrence of this species. 
Wave exposure - Wave exposure is also one of the most important factors structuring coastal communities (Lewis 1964). In the models, this parameter contributed to the prediction of the biomass of both $L$. digitata and L. hyperborea, especially through the interaction with depth and light availability. With its flexible stipe and deeply divided blade L. digitata is well adapted to fast, turbulent water flow and mechanical stress. Our results are also in line with studies that have found that growth and densities of L. hyperborea were significantly influenced by wave exposure (Kain, 1971; Bekkby et al, 2009). Pedersen (2012) has also shown that the biomass and production of L. hyperborea doubled along a gradient from lowto high-exposure sites.

Current exposure - The influence of exposure to current was mainly expressed through the interaction with the proximity of kelp to the sediment, used here as a proxy for sand scouring. This parameter contributes significantly to the presence of $L$. digitata and $L$. hyperborea as well as to the biomass of the latter, mainly by interacting with depth. Perez and Audouin (1973) indicated that with the proximity of sandy areas, L. hyperborea populations were scattered, particularly at their upper levels. L. digitata then occupies the space left free, mixed with other species such as Saccharina latissima. Sediment proximity -Percentages of explained deviance showed the strong role of sediment proximity while simply expressed as the distance from unconsolidated sediments. Similar results were obtained by Gorman et al. (2012) in the Bay of Morlaix. The consistency of the statistical model results with in situ observations seems to highlight sand scouring as a significant factor limiting the development and growth of kelp species or inducing higher mortality rate. In winter, high swell energy removes the sand and the scouring effect has a bearing on recruitment at first and on the growth of individuals at a later stage. Immersion was only expressed in the L. digitata presence/absence model especially with the interaction of temperature. This result seems to reflect the ability of this species to tolerate desiccation during extreme low tides. The much more flexible stipes of this species enable the thalli to lie flat on the seabed with the uppermost covering the lower ones and thereby protecting them against desiccation (Birkett et al, 1998, Lüning 1990 in Werner). Our results also showed that some environmental factors affecting the distribution of the species at a biogeographical scale (Bekkby et al, 2009. Bonneti, 2009, Meleder, 2010) may also have an influence at a local scale. This is the case for temperature. Despite its small variation across the study area $\left(\sim 1^{\circ} \mathrm{C}\right.$ spatial variation in each season), it seems to control the 
correlation side-effect than a real influence, or could be integrative of annual variations of temperature encountered in the area.

\subsubsection{Kelp species distribution and standing stock estimation}

Several studies have performed predictive mapping of kelp presence/absence (Bekkby et al, 2009, Meleder et al. 2010, Bekkby and Moy. 2011) but to our knowledge, only a few concerned kelp biomass mapping (Gorman et al, 2012). In this study, we investigated occurrence as well as biomass because of the importance of estimating standing stocks for the management of this resource.

Kelp species distribution maps considered in the present study showed a well marked vertical zonation between the two main species present in the Archipelago. The distribution of $L$. digitata mainly between +2 and $-5 \mathrm{~m}$ seems to be in line with the narrow distribution known for this species along the Brittany coast (Arzel 1998, Kerambrun 1984, Perez et Audouin 1973, Derrien et al., 2013) where it is limited to the infra-littoral fringe and upper subtidal. However, when comparing this distribution to that found on the coasts of Calvados in Normandie, where L. hyperborea is absent and where L. digitata grows to a depth of up to 9m (Perez and Audouin 1973), the question arises whether the narrowness of L. digitata distribution on the Brittany coasts is not the result of competition between these two kelp species.

L. hyperborea can spread from the extreme limit of low waters to depth of up to $40 \mathrm{~m}$ when the clarity of the water allows their extension (Perez et Audouin 1973, Floc'h 1982, Castricfey, 1973). Derrien et al (2013) showed that kelp can grow to approximately $30 \mathrm{~m}$ in clear water at offshore sites (Ushant Island), a value very closed to the $29 \mathrm{~m}$ observed at Molène during our study, even if $85 \%$ of the biomass is limited to depths less than $15 \mathrm{~m}$.

Saccorhiza polyschides predicted distribution must be considered with great caution, as it is an annual opportunistic algae. Living at the same level as L. digitata and L. hyperborea as shown by potential occurrence maps, Sacchorhiza polyschides competes with these two species, while invading the space left by them (Perez and Audouin, 1973). The greater production and high growth rate of this species explains the pioneering role of Sacchorhiza in the colonization of rocky bottoms. This species settles preferentially in unfavourable conditions for the others, whether in contact with sand or in areas devastated by storms (Chassé C. et Le Gendre A.F., 1977). But when L. digitata and L. hyperborea populations are abundant, Sacchoriza polyschides is very poorly represented. These variations make the mapping of this species highly uncertain (residual deviance of $48.27 \%$ ), explaining why a biomass model was not performed. 
In our study, occurrence of L. digitata and its biomass appeared to have spatially correlated distributions. In contrast, the distribution of biomass of L. hyperborea do not necessarily follow the same spatial organization as the probability of presence. This species clearly shows an increasing gradient of biomass along the SE/NW axis. The south-western part exhibits lower biomass values despite high presence probabilities. This observation was made by kelp harvesters (Laurans, Pers. Comm.) and confirmed by in situ measurements. A higher frequency of S. polyschides in the SE area suggested a greater competition with $L$. hyperborea in this sector.

The median estimated area occupied by L. digitata ( $4686 \mathrm{ha}$ ) was greater than that so far predicted in the literature. The nearest value is 3500 ha estimated by Kerambrun (1984). Those estimated by Piriou, 1987 (1600 ha) and Arzel, 1998 (1045 ha) were significantly lower. The latter used a very approximate method of interviewing harvesters so that their estimation did not include areas where $L$. digitata was certainly present but as combined with other algae, irrelevant for harvesting. By contrast, the estimated values in the present study concerned the entire Molène Archipelago area regardless of the density or biomass locally encountered. The two main species, L. digitata and L. hyperborea, totalized an average area estimated at 15738 ha which is significantly greater than the 10900 ha estimated by Kerambrun (1984).

The cross-validation method was chosen in this study to evaluate the model performance as was done by Bonetti (2009). All samples were included in the modelling process for a better spatial representativeness of $L$. digitata and L. hyperborea distributions. Besides, we brought to light the fact that the delineation of L. digitata harvesting using the RECOPESCA VMS data, which could be considered as external data, strongly reaffirmed the model performance as harvesting locations were consistent with the predicted $L$. digitata distributions. Our results also pointed out that relatively large-scale predictors such as temperature were able to improve the performance of the model and were found to be betteras good contributors to fit the model at a local scale. However, due to resolution incompatibility ( $5 \mathrm{~m}$ bathymetry and $1 \mathrm{~km}$ for temperature), some artefacts were locally observed when zooming-in on certain areas.

\subsubsection{Application of predictive habitat models for kelp management}

There is a need to improve management measures for kelp exploitation in Brittany with regards to industrial demand. The evolution of kelp production on the Brittany coast increased from 30000 to 60000 tons in the 80's and since 1991 fluctuates between 50000 and 70000 tons (Davoult et al. , 2011). Such fluctuations depend on several parameters such 
as available biomass, weather conditions for harvesting and industrial demand. Today, the Molène Archipelago, which provides more than half of total landings, is the ideal area to develop new tools. By providing information on where important kelp habitats can be found and monitored in the PNMI, the potential of the proposed method in developing integrated solutions for sustainable coastal management can also be demonstrated.

Werner et al. (2004) indicated that there are two main tools for regulating the harvest of seaweed with respect to natural marine resources exploitation. The first can be defined by the number of licenses and the second consists in regulating harvesting times and quotas. We focused on the spatial distribution of biomass to make proposals for defining management measures of the two harvested kelp species. To provide detailed estimates on standing stocks of kelp beds suitable for harvesting, the overall accuracy or sensitivity of the model is not sufficient if end-users or managers are to draw appropriate conclusions on the usefulness and limitations of the model. Hence, we calculated the estimation of the confidence interval for areas covered by kelp as well as their biomass. For both species, the interval range is much greater for their biomass than for the area they cover.

\section{Laminaria digitata}

Currently, as L. digitata is supposed to have sufficient recruitment and growth (Laurans 2010), most of these kelp beds are harvested year after year. There is only an annual and global quota that is set at $30 \%$ of the standing stock.

The comparison with the production data provided by RECOPESCA, which gives an estimated standing stock (median of the model) calculated according to a gridded area (1min by $1 \mathrm{~min}$ ), shows a heterogeneous exploitation rate of the stock (Fig. 11). With a standard deviation of 23 points, the ratio of harvested biomass to estimated standing stock varies considerably between sectors of the archipelago although its average of $21 \%$ remains below the global quota value. This tendency to an uneven harvesting pressure was confirmed by consulting professionals (Laurans, pers. comm). However, we point out the exceptional maximum value of $111 \%$ estimated locally near Molène Island. This is probably due to an underestimation of the model on the lower limit of $L$. digitata distribution where the transition towards $L$. hyperborea takes place. Also, the bathymetric gradient was particularly low. Underestimation of the model can also be associated with an overestimation of production for this statistical rectangle. Indeed, the integration of exploitation data to statistical rectangles is determined proportionally to the time spent by vessels and the total exploited quantity and is also based on the hypothesis that the fishing yield is the same in each rectangle. However, stock 
distribution maps show that this assumption is not necessarily true throughout the study area.

Figure 11 also shows that the harvesting activity is currently taking place mainly in the north part of the Molène Archipelago. It may also offer a guide for harvesting to expand or to redirect some of the current harvesting towards the south-eastern area of Molène which is not being exploited despite high biomass. This is probably due to the constraints related to the proximity of Lanildut, the landing harbour on the mainland (Fig. 1) as well as to treatment facilities.

The introduction of fallow periods or periods of low harvest would be advisable. These measures are thought to be sufficient to ensure significant sustainable harvesting by increasing the average plant age within the populations. As L. digitata has a relatively short regeneration time with a life span of 3 years (Arzel, 1998 ; Lüning, 1990), it is also seen as a method to limit the development of S. polyschides, because the latter is an annual species which dies off in winter. Indeed, the occurrence of Saccorhiza polyschides observed in recent years seems to be related to biomass variations of $L$. digitata beds (Engelen et al., 2011). Local over-harvesting (Arzel, 1998) or impact of climate change (Raybaud et al, 2013) may explain these situations. These two species compete but to our knowledge no research has been undertaken to explain the mechanisms of this interaction.

It is important to give a special attention to the development of S. Polyschides. The increase in abundance of this species is leading to economic losses for the fishermen. In fact, the industry rejects any L. digitata containing over $20 \%$ S. polyschides as described in the current contract between harvesters and the industry. As mentioned earlier, this kelp is an opportunistic fast growing and annual species (Chassé and Le Gendre, 1977). It could rapidly colonize free space created after harvesting. Over-harvesting could lead to increasing abundance of S. polyschides and the consequential replacement of L. digitata.

One of the harvesting strategies that can be recommended here, would be to start the exploitation of $L$. digitata early in the season to rapidly eliminate $S$. polyschides individuals before their fronds reach their maximum size. This will allow L. digitata to grow better as it can take better advantage of the newly available light.

\section{Laminaria Hyperborea}

L. hyperborea has been harvested in the Molène Archipelago since 1995. Very limited information is available about the exact location and production of this newly exploited species. To anticipate an increase in fishing effort which is suspected in the coming years by 
managers, a number of precautions can be suggested to obtain a sustainable management of this kelp species.

A harvesting plan has been in place for fifteen years. Fishermen have introduced fallow periods as a self-management measure. The coast is thus divided into sectors where when an allocated quota of $20 \%$ of the estimated biomass is once reached, it causes the closure of the area for five years.It would be interesting to improve this plan based on new knowledge gained through our study. In fact, the zoning which supports the actual L. hyperborea management plan is quite extensive (Fig. 12). Using the RECOPESCA data, one could suggest a finer one minute grid along with the current biomass model developed. The advantage would be that the overall distribution of exploitation would be more in line with the biomass present and would thus avoid any local concentration. Figure 12 shows the available quotas as a result of applying the $20 \%$ rule of estimated biomass to this rezoning of the archipelago. Given the SE-NW gradient observed in the distribution of biomass, it also suggests that the $20 \%$ quota could be modulated depending on the local available stock. Similar management strategies are currently being applied in Norway (Vea et al. 2011), where managers also apply the 5-year closure period described above. This duration would require more detailed local studies on the population dynamics of $L$. hyperborea in the Molène archipelago. To somehow optimize L. hyperborea exploitation, results obtained for stock distribution according to the bathymetric gradient suggest that harvesting activity could target the area between 5 and $15 \mathrm{~m}$ that hosts the majority of the L. hyperborea standing stock. Two zones are to be avoided : the first lies between 0 and $3 \mathrm{~m}$ where L. digitata is assumed to be mixed with L. hyperborea which implies an additional sorting operation that is not economically interesting. The other zone without economical interest for L. hyperborea kelp exploitation lies beyond $15 \mathrm{~m}$ as presence decreases and biomass only represent $15 \%$ of the estimated standing stock.

Besides, it is important that end users, PNMI managers as well as fishermen, are aware that kelp habitat maps obtained can be improved and updated on an ongoing basis due to the increase in knowledge, from physical data to the biological cycles of species. Despite this limitation, the results of kelp modelling and mapping were very encouraging and increased knowledge significantly on the spatial distribution of the main kelp species of the Molène Archipelago.

\subsubsection{Issues related to kelp species predictive mapping and management}


Regarding kelp distribution, the design for collecting field data is crucial for modeling and making spatial predictions. Sampling strategy could be refined by a better analysis of the model sensitivity, especially when considering the number of samples used as well as the range and resolutions of data related to the physical predictor inputs. A better resolution of physical parameters that were shown to have an influence on kelp species would improve predicted distributions and allow a better management plan. Indeed, some low resolution parameters have an influence on the quality of the model. Knowing the resolution differences of available environmental parameters, we compared for instance, the probability of presence of $L$. digitata with a model not incorporating large scale data $(1 \mathrm{~km})$. The selected model in this case shows a lower AUC of 0.78 (compared to 0.96 ) as also a residual deviance of $36.61 \%$ (compared to $21.1 \%$ ).

Observations related to the size structure showed clearly that the population dynamics is not homogeneous throughout the study area. The separation of juveniles (unharvested individuals) would be a new step towards a better management by integrating observed densities. This separation would identify areas and therefore the parameters which determine the recruitment of kelp (Pedersen et al., 2012).

Over-harvesting practices may also lead to the fragmentation of populations beyond their demographic viability. Several studies demonstrated that L. digitata populations along the Brittany coast were strongly influenced by habitat discontinuities (Billot et al. 2003; Valero et al., 2011). Their analyses clearly showed an effect of small population sizes on genetic instability of isolated populations. Knowing the role of Molène L. digitata populations in the gene flow (Couceiro et al., 2013), they can help depleted populations in adjacent areas to recover. Thus, fragmentation could be an additional monitoring indicator to ensure their sustainable exploitation.

Further aspects should be considered for developing management programs for kelp resources and ensure sustainability. In fact, habitats depicted in the maps are never static and may have seasonal or multi-annual cycles. In addition to spatial regulations on harvestable biomass, harvesting season and fallow periods should be considered with respect to each species' growth strategy and their capacities of stock renewal. Indeed, a specific monitoring program repeated annually may help integrate temporal variations of kelp distribution. The establishment of areas with no harvesting in 2014 is a complementary approach to the tools proposed in this study. This would provide objective information on the state of conservation of kelp forests and quantify harvesting impact in time. 
The development of the RECOPESCA program and its extension to the entire fleet would also be an opportunity to better manage and monitor the evolution of harvesting. With such equipment, it would be easier to follow the implementation of a refined zoning plan and more specifically monitor the areas identified as the most sensitive. If new measures were applied, they should be implemented in consultation with fishermen. A system should be also designed to assess their relevance.

\section{Conclusions}

This study showed that the adopted strategy and data processing methodology readily performs effective mapping of kelp species of Molène Archipelago. To our knowledge, this is the first time in France that such an approach has been implemented to help kelp management by providing standing stock of the main harvested species distributions. Our study thereby provides a direct link between researchers, managers and fishermen.

By an integrated approach combining optical and acoustic techniques, information on the sea bottom has been greatly improved. Accurate maps on the topography as well as hard substrates were thus obtained and were a key input for kelp forest habitat mapping.

Our study also demonstrated the successful application of predictive habitat models to provide kelp species and biomass distributions along temperate coastlines. In fact, parameters were statistically significant in the model to spatially represent kelp occurrence and biomass along Brittany's coast. They were also ecologically coherent and in agreement with previous studies. The performance could be increased by improving the resolution of environmental predictors that significantly control kelp distribution.

Although these predictive modeling tools cannot completely replace direct and overall observation of seabed, they can provide a comprehensive picture of some habitats that are compatible with marine ecosystem management. They also enable a significant gain of money and time compared to direct methods. The generated spatial product provides useful support to help managers by enhancing knowledge of standing stocks, distributions as well as their confidence intervals, for the two main harvested species $L$. digitata and $L$. hyperborea. Identifying productive areas and apprehending the temporal dynamics of kelp stocks may be of major importance for long-term management. 
Description and sources of various physical parameters used for modelling.

\begin{tabular}{|c|c|c|c|}
\hline $\begin{array}{l}\text { Physical } \\
\text { parameter }\end{array}$ & Source & Description & Resolution \\
\hline $\begin{array}{l}\text { Bathymetry } \\
\text { and } \\
\text { derivatives }\end{array}$ & $\begin{array}{l}\text { From the } \\
\text { present } \\
\text { study }\end{array}$ & $\begin{array}{l}\text { Bathymetry is a direct result from acoustic and optical data treatment, } \\
\text { which is detailed further in } \$ 2.5 \text {. Classical topographic indicators can be } \\
\text { derived from the bathymetry such as the slope, the benthic position } \\
\text { index (BPI) or the hillshade. Combination of BPI and the slope allowed } \\
\text { to build a } 4 \text { class factor indicating the position of 1-peaks, 2-troughs, 3- } \\
\text { flats and 4-slopes. }\end{array}$ & $5 \mathrm{~m}$ \\
\hline $\begin{array}{l}\text { Light } \\
\text { availability } \\
\text { KdPAR (m-1) }\end{array}$ & $\begin{array}{l}\text { MERIS } \\
\text { satellite }\end{array}$ & $\begin{array}{l}\text { Light fraction that reaches a given depth is calculated with } \mathrm{Fr}=\mathrm{e}-\mathrm{h} / \mathrm{Dm} \text {, } \\
\text { where } \mathrm{h} \text { is the depth and Dm }=\text { KdPAR- } 1 \text { is sometimes called the average } \\
\text { depth of penetration. The attenuation coefficient of light KdPAR } \\
\text { ("diffuse attenuation coefficient of downwelling photosynthetically } \\
\text { available radiation") was estimated from the radiance measured by } \\
\text { MERIS (MEdium Resolution Imaging Spectrometer Instrument), and was } \\
\text { calculated every } 3 \text { hours to account for tides, Fr being equal to } 1 \text { when } \\
\text { the area had emerged. Light fraction was then averaged to provide an } \\
\text { annual map. }\end{array}$ & $250 \mathrm{~m}$ \\
\hline $\begin{array}{l}\text { Tidal current } \\
\left(\mathrm{kg} \cdot \mathrm{m}^{2} \cdot \mathrm{s}^{-2}\right)\end{array}$ & $\begin{array}{l}\text { MARS 2D } \\
\text { model }\end{array}$ & $\begin{array}{l}\text { Tidal current data were issued from the MARS 2D hydrodynamical } \\
\text { model with a resolution of } 250 \mathrm{~m} \text {. Two indicators were extracted: kinetic } \\
\text { energy and direction of currents. Kinetic energy was calculated with } \\
\mathrm{E}=1 / 2 * \mathrm{~m} * \mathrm{v}^{2} \text {, where } \mathrm{m} \text { is salt water density }(=1027 \mathrm{~kg} / \mathrm{L}) \text { and } \mathrm{v} \text { the } \\
\text { velocity. Direction of current was used to calculate the exposure to } \\
\text { current, which indicated whether an area was facing currents or not. }\end{array}$ & $250 \mathrm{~m}$ \\
\hline $\begin{array}{l}\text { Waves } \\
\left(\mathrm{kg} \cdot \mathrm{m}^{2} \cdot \mathrm{s}^{-2}\right)\end{array}$ & $\begin{array}{l}\text { MARS 2D } \\
\text { model }\end{array}$ & $\begin{array}{l}\text { Wave direction and kinetic energy were issued from the wave model. } \\
\text { Wave exposure was calculated similarly to current indicators. }\end{array}$ & $200 \mathrm{~m}$ \\
\hline $\begin{array}{l}\text { Sediment } \\
\text { proximity }\end{array}$ & $\begin{array}{l}\text { From the } \\
\text { present } \\
\text { study }\end{array}$ & $\begin{array}{l}\text { Sediment proximity was used as proxy of sand scouring influence. It was } \\
\text { calculated from current/wave and was approximated by calculating the } \\
\text { distance from sediments to rocky areas, following the average direction } \\
\text { of current/wave. Effect of sand scouring is non linear and rapidly } \\
\text { decreases with distance. This was ranked in four classes: ]0,20m], } \\
\text { ]20,50m], ]50,100m] and }>100 \mathrm{~m} \text {, respectively coded from } 1 \text { to } 4 \text {. }\end{array}$ & $5 m$ \\
\hline $\begin{array}{l}\text { Tempeature } \\
\left({ }^{\circ} \mathrm{C}\right)\end{array}$ & satellite data & $\begin{array}{l}\text { The study area does not present water stratification (ref), thus sea } \\
\text { surface temperature from satellites is a good proxy (substitute?) for } \\
\text { bottom temperatures. Annual average summer and spring temperatures } \\
\text { were tested. Temperatures for the other seasons were spatially } \\
\text { correlated either with the summer (autumn) or the spring (winter) ones. }\end{array}$ & 1 km \\
\hline $\begin{array}{l}\text { Total } \\
\text { Suspended } \\
\text { Matter } \\
\text { (g.m-3) }\end{array}$ & satellite data & $\begin{array}{l}\text { Total suspended matter (TSM) is the set of visible and insoluble solid } \\
\text { matter present in water the size of which generally ranges from } 1 \mu \mathrm{m} \text { to } \\
1 \mathrm{~cm} \text {. TSM is considered as a substitute for turbidity and affects the light } \\
\text { available for kelp. . Although it is included in the calculation of KdPAR to } \\
\text { estimate the fraction of light reaching the bottom, its direct effect was } \\
\text { tested in the models. TSM were issued from satellite data. Summer, } \\
\text { winter and spring concentrations were tested. }\end{array}$ & 1 km \\
\hline $\begin{array}{l}\text { Chlorophyll a } \\
\left(\mathrm{mg} \cdot \mathrm{m}^{-3}\right)\end{array}$ & satellite data & $\begin{array}{l}\text { The concentration of chlorophyll-a is a proxy for estimating the } \\
\text { concentration of dissolved inorganic nutrients favourable to primary } \\
\text { production and potentially for the development of kelp. Concentrations } \\
\text { of chlorophyll-a were provided by satellite data. Annual average, winter } \\
\text { and spring concentrations were tested. Chlorophyll-a for the other } \\
\text { seasons were spatially correlated either with the winter or the spring } \\
\text { contents. }\end{array}$ & $1 \mathrm{~km}$ \\
\hline $\begin{array}{l}\text { Salinity } \\
\text { (\%o) }\end{array}$ & $\begin{array}{l}\text { ECOMARS3D } \\
\text { hydrodynam } \\
\text { ical model }\end{array}$ & $\begin{array}{l}\text { Annual, winter and spring values were tested. Other temporal salinity } \\
\text { indicators were spatially correlated with one of the three values. }\end{array}$ & $3 \mathrm{~km}$ \\
\hline Oxygen & $\begin{array}{l}\text { ECOMARS3D } \\
\text { hydrodynam } \\
\text { ical model }\end{array}$ & $\begin{array}{l}\text { Annual, winter and spring concentrations of dissolved oxygen values } \\
\text { were tested. Other temporal oxygen indicators were spatially correlated } \\
\text { with one of the three concentrations. }\end{array}$ & 3 km \\
\hline
\end{tabular}




\section{Acknowledgements}

This research was supported by funding from "Agence des aires marines protégées" and Ifremer. The Parc Naturel Marin d'Iroise (PNMI), the French hydrographic service (SHOM), and Genavir staff are acknowledged for running Lidar and acoustic data survey. Our gratitude also goes to Céline Cordier, Julie Tourolle, Mickaël Vasquez, Jacques Populus, Xavier Caisey, Jean-Dominique Gaffet as well as PNMI and Ifremer divers for their assistance during various fieldwork and data processing. Many thanks to the Prévimer team for providing physical and environmental data, without which the modeling approach as implemented in this study would not be possible. This work benefited from the European FP7 IQmulus project and the French program Labex Mer (ANR-10-LABX-19-01).

\section{References}

Ardhuin, F., Dumas, F., Bennis, A.C., Roland, A., Sentchev, A., Forget, P., Wolf, J., Girard, F., Osuna, P., Benoit, M., 2012. Numerical wave modeling in conditions with strong currents: dissipation, refraction and relative wind. J. Phys. Oceanogr. 42, 2101-2120.

Arzel P., 1998. Les laminaires sur les côtes bretonnes, évolution de l'exploitation et de la flottille de pêche, état actuel et perspectives. Ifremer Plouzané, 139pp.

Billot, C., Engel, C.R., Rousvoal, S., Kloareg, B., Valero, M.,2003. Current patterns, habitat discontinuities and population genetic structure: the case of the kelp Laminaria digitata in the English Channel. Mar Ecol Prog Ser. 253, 111-121.

Bajjouk, T., Guillaumont, B, Populus, J., 1996. Application of airborne imaging spectrometry system data to intertidal seaweed classification and mapping. Hydrobiologia 327, 463-471.

Bekkby, T., Frithjof, E., Moy , Kroglund, T., Janne, K., Gitmark , Mats Walday , Rinde, E., \& Kjell Magnus Norderhaug , 2009 (a). Identifying Rocky Seabed Using GISModeled Predictor Variables. Marine Geodesy 32, 379-390.

Bekkby, T., Rinde, E., Erikstad, L., Bakkestuen, V., 2009 (b). Spatial predictive distribution modelling of the kelp species Laminaria hyperborea. ICES Journal of Marine Science 66, 2106-2115.

Bekkby, T., Frithjof, E., Moy, 2011. Developing spatial models of sugar kelp (Saccharina latissima) potential distribution under natural conditions and areas of its disappearance in Skagerrak. Estuarine. Coastal and Shelf Science 95, 477-483.

Ben Moussa, H., 1987. Contribution de la télédetection satellitaire à la cartographie des végétaux marins: Archipel de Molène (Bretagne/France). Thèse de I'Université d'Aix-Marseille II. 122 p + annexes.

Bonetti, C., Populus, J., 2008. Predictive mapping of benthic marine habitats: logistic regression modeling applied to kelp forests in Brittany (France). Brest, Ifremer, DYNECO/AG, Report. 25 pages + annexes. 
Birkett, D.A., Maggs, C.A., Dring, M.J., Boaden, P.J.S., 1998. Infralittoral reef biotopes with kelp species. An overview of dynamic and sensitivity characteristics for conservation management of marine SACs, 4. UK Marine SACs Project. $174 \mathrm{p}$.

Cameron, A., Askew, N., 2011. EUSeaMap - Preparatory Action for development and assessment of a European broad-scale seabed habitat map final report. $227 \mathrm{p}$.

Castric-Fey, A., Girard-Descatoire, A., L'Hardy-Halos, M.T., Derrien-Courtel, S., 2001. La vie sousmarine en Bretagne. Découverte des fonds rocheux. Association pour la découverte du monde sousmarin. Collection "Les Cahiers naturalistes de Bretagne" du Conseil Régional de Bretagne. Edition et diffusion BIOTOPE.

Chassé , C., Le Gendre, A.F., 1977. Production Primaires des grandes algues en Bretagne. Rapport contrat CNEXO 76-5288, 56p.

Christie, H., Jorgensen, N.M., Norderhaug, K.M., Waage-Nielsen, E., 2003. Species distribution and habitat exploitation of fauna associated with kelp (Laminaria hyperborea) along the Norwegian coast. J Mar Biol Assoc UK 83, 687-699.

Chust, G., Grande, M., Galparsoro, I., Uriarte, A., Borja, Á., 2010. Capabilities of the bathymetric Hawk Eye LiDAR for coastal habitat mapping: A case study within a Basque estuary. Estuarine, Coastal and Shelf Science 89, 3, 10 October 2010, 200-213.

Connor, D., 2005. EUNIS marine habitat classification: application testing and improvement. MESH project. 16pp.

Couceiro, L., Robuchon, M., Destombe, C., et al. Aquatic Living Resources 26, 2, 197-205 Published: April-June 2013

Cuadrado, D.G., Gómez, E.A., 2011. Morphodynamic characteristics in a tidal inlet: San Blas, Argentina. Geomorphology 135, 203-211.

Davoult, D., Engel, C.R., Arzel, P., Knoch, D., Laurans, M., 2011. Environmental factors and commercial harvesting: exploring possible links behind the decline of the kelp Laminaria digitata in Brittany, France. Cahiers de Biologie Marine 52, 4, Special Issue: SI, 429-434.

Dayton, P.K., Tegner, M.J., Edwards, P.B., Riser, K.L., 1998. Sliding baselines, ghosts, and reduced expectations in kelp forest communities. Ecol. Appl. 8,309-322.

Derrien-Courtel, S., Le Gal, A., Grall, J., 2013. Regional-scale analysis of subtidal rocky shore community. Helgol. Mar. Res. 67, 697-712.

Ehrhold, A., Hamon ,D., Guillaumont, B., 2006. The REBENT monitoring network, a spatially integrated, acoustic approach to surveying nearshore macrobenthic habitats: application to the Bay of Concarneau (South Brittany, France). ICES J. Mar. Sci. 63, 1604-1615.

Elith, J., Graham, C., Anderson, R., Dudik, M., Ferrier, S., Guisan, A., Hijmans, R., Huettmann, F., Leathwick, J., Lehmann, A., Li, J., Lohmann, L., Loiselle, B.A., Manion, G., Moritz, C., Nakamura, M., Y. Nakazawa, Y., Overton, J.M.C.M., Peterson, A.T., Phillips, S., Richardson, K., Scachetti-Pereira, R., Schapire, R., Soberón, J., Williams, S., Wisz, M., Zimmermann, N., 2006. Novel methods improve prediction of species' distributions from occurrence data. Ecography 29, 129-151.

Engelen, A. G., Lévèque, L. , Destombe, C., Valero, M., 2011. Spatial and temporal patterns of recovery of low intertidal Laminaria digitata after experimental spring and autumn removal. Cah.Biol.Mar. 52,441-453. 
Erikstad, L., Bakkestuen, V., Bekkby, T., Halvorsen, R.,2013. Impact of Scale and Quality of Digital Terrain Models on Predictability of Seabed Terrain Types Marine Geodesy 36, 2-21

Fowler-Walker, M.J., Connell, S.D., 2002. Opposing states of subtidal habitat across temperate

913

914

915

916

917

918

919

920

921

922 Australia: consistency and predictability in kelp canopy-benthic associations. Mar. Ecol. Prog. Ser. 240, 49-56

Floc'h, J.Y., 1967. Cartographie de la végétation marine et observations écologiques dans l'archipel de Molène. Thèse de Doctorat, Université de Rennes, 135 p.

Flood, M., Gutelius, B., 1997: Commercial implications of topographic terrain mapping using scanning airborne laser radar. Photogrammetry Engineering and Remote Sensing LXIII, 327-29; 363-66.

Frangoudes, K., 2011. Seaweeds Fisheries Management in France, Japan, Chile and Norway, Cah.Biol.Mar. 52, 517-525.

Frangoudes, K., Jacob, C., Lesueur, M., Mesnildrey, L., 2012. Etats des lieux et perspectives de la filière des macro-algues en Europe. www.NETALGAE.EU.

Gorman, D., Bajjouk, T., Populus, J., Vasquez, M., Ehrhold, A., 2012. Modeling kelp forest distribution and biomass along temperate rocky coastlines. Marine Biology 160,2, 309-325.

Guilcher, A., 1959. L'archipel de Molène (Finistère). Etude morphologique. Revue de Géographie Physique et de Géologie Dynamique,2, II (fasc. 2),81-96.

Guillaumont, B., Bajjouk, T., Talec, P.,1997. Seaweed and remote sensing: a critical review of sensors and data processing. In:Round FE, Chapman DJ (eds) Progress in phycological research. Biopress, Bristol, 213-282.

Guisan, A., Zimmermann, N.E., 2000. Predictive habitat distribution models in ecology. Ecol Model $135,147-186$.

Guisan, A., Edwards, J., Thomas, C., Hastie, T., 2002. Generalized linear and generalized additive models in studies of species distributions: setting the scene. Ecol. Model. 157, 89-100.

Hiller, T.M., Hogarth, P., 2005. The Use of Phase Measuring (Interferometric) Sonars: Choosing Appropriate Data Processing Methodologies. Intern. Hydrograp. Rev., 6, 1.

Holmes, K.W., Van Niel, K.P., Radford, B., Kendrick, G.A., Grove, S.L., 2008. Modelling distribution of marine benthos from hydroacoustics and underwater video. Cont Shelf Res 28, 1800-1810.

Hooper, D.U., Chapin, F.S., Ewel, J.J., Hector, A., Inchausti, P., Lavorel, S., Lawton, J.H., Lodge, D.M., Loreau, M., Naeem, S., Schmid, B., Seta, H.," LA“" Symstad, A.J., Vandermeer, J. , Wardel, D.A., 2005. Effects of biodiversity on ecosystem functioning: a consensus of current knowledge. Ecological Monographs 75,1, 3-35.

Irish, J.L., Lillycrop, W.J., 1999. Scanning laser mapping of the coastal zone: the SHOALS system. ISPRS J Photogrammetry Remote Sens 54, 123-129.

Kain, J. M., 1971. The biology of Laminaria hyperborea 6. Some Norwegian populations. Journal of the Marine Biological Association of the UK, 51, 387-408.

Keil, P., Belmaker, J, Wilson, A.M., Unitt, P., Jetz, W, 2013. Downscaling of species distribution models: a hierarchical approach. Methods in Ecology and Evolution, 4,1, 82-94.

Kepel, R. C., 1995. Recherches méthodologiques pour l'estimation de la ressource en laminaire sur les côtes bretonnes. Thèse $3^{\text {ème }}$ cycle, Université de Bretagne Occidentale, $121 \mathrm{p}$. 
Kerumbrun, L., 1984. Contribution à l'étude de la fertilité des fonds rocheux côtiers de Bretagne. Thèse de doctorat 3ème cycle de l'Université de Bretagne Occidentale. 150 p. + annexes.

952

953

954

955

956

957

958

959

960

961

962

963

964

965

966

967

968

969

970

971

972

973

974

975

976

977

978

979

980

981

982

983

984

985

986

987

988

989

990

Laurans, M. , Huet, J. , Martin, S., Miossec, D., Caroff, N., Roudaut, Pitel, M., Garren, F., Barone H., Rioual, C., Arzel, P., 2010. 20 années de suivi d'une population de Laminaria digitata : quelles connaissances sur la dynamique. International Workshop "The management of Marine Algal Resources", 4th and 5th of July 2010. Joint Research Unit AMURE at the University of Brest (UEB).

Leblond, E., Berthou, P., Laurans, M., Woerther, P., Quemener, L., 2008. The Recopesca project: a new example ofparticipative approach to collect in-situ environmental and fisheries data using fisheries vessels of opportunity. ICES CM 2008/ R:16.

Leclerc, JC., 2013. Biodiversité, structure et fonctionnement trophique des communautés associées à Laminaria hyperborea, en conditions naturelles et exploitées, en Bretagne. Th. Université Pierre et Marie Curie (UPMC).

Lecornu, F., De Roeck, Y.H., 2009. PREVIMER - Observations \& Prévisions Côtières, - La Houille Blanche, N¹ (Mars 2009), pp. 60-63 - DOI: 10.1051/lhb:2009006

Lefsky, M.A., Cohen, W.B., Parker, G.G., Harding, D.J., 2002. Lidar remote sensing for ecosystem studies. Bioscience, Jan 2002, 52, 1, Research Library, p. 19

Le Gall B., Authemayou C, Ehrhold A., Paquette J.L., Bussien D, Chazot G, Aouizerat A, Pastol Y., 2014. LiDAR offshore structural mapping and $\mathrm{U} / \mathrm{Pb}$ zircon/monazite dating of Variscan strain in the Leon metamorphic domain, NW Brittany, Tectonophysics (2014), http://dx.doi.org/10.1016/i.tecto.2014.05.026

Legrand, H., Lenfant, P., Sotheran, I., Foster-Smith, R., Galzin, R., Maréchal, J.P., 2012. Mapping marine benthic habitats in Martinique (French West Indies). Caribbean Journal of Science 46, 2,3, 267-282.

Lüning, K., 1990. Seaweeds: their environment, biogeography, and ecophysiology. John Wiley \& Sons, Inc., New York.

Mann, K.H., 1973. Seaweeds: their productivity and strategy for growth. Science182, 975-981

Méléder, V., Populus, J., Guillaumont, B., Perrot, T., Mouquet, P., 2010. Predictive modelling of seabed habitats: case study of subtidal kelp forests on the coast of Brittany, France. Mar Biol. 157, 15251541.

Mitchell, N.C., Hughes Clarke, J.E., 1994. Classification of seafloor geology using multibeam sonar data from the Scotian Shelf: Marine Geology 121, 143-160.

Norton, T.A., Burrows, E.M., 1969a. The environmental control of the seasonal development of Saccorhiza polyschides (Light.) Blatt. International Seaweed Symposium, 287-296

Parrott, D.R., Todd, B.J., Shaw, J., Hughes Clarke, J.E., Griffin, J., MacGowan, B., Lamplugh, M., Webster, T., 2008. Integration of Multibeam Bathymetry and LiDAR Surveys of the Bay of Fundy, Canada. . Proceedings of the Canadian Hydrographic Conference and National Surveyors Conference 2008. Paper 6-2, $15 \mathrm{p}$.

Pedersen, M.F., Nejrup, L.B., Fredriksen, S., Christie, H., Norderhau, K.M., 2012. Effects of wave exposure on population structure, demography, biomass and productivity of the kelp. Laminaria hyperborea. Mar Ecol Prog Ser 451, 45-60. 
Perez, R., Audouin, J., 1973. Répartition des grands champs d'algues brunes sur les côtes françaises de la Manche occidentale entre I'lle Grande et l'île de Siec. Science et Pêche, Bull. Inst. Pêches marit. 226, 3-12.

Piriou, J.Y, 1987. Cartographie de la végétation marine sur le littoral Bas-Léonard (Finistère-nord). Programme Peps Vegma. Rapport Ifremer Réf. DERO-87.22-EL. 48 p.

Raffin, C., 2003. Bases biologiques et écologiques de la conservation du milieu marin en mer d'Iroise. Thèse de doctorat de l'Université de Bretagne Occidentale, 430p. + 9 annexes.

Raybaud, V, Beaugrand, G, Goberville, E, Delebecq, G, Destombe, C, et al., 2013. Decline in Kelp in West Europe and Climate. PLoS ONE 8(6): e66044.doi:10.1371/journal.pone.0066044.

Rochette, S., Rivot, E., Morin, J., Riou, P., Le Pape, O., 2010. Effect of nursery habitat degradation on flatfish population: application to Solea solea in the Eastern Channel (Western Europe). J. Sea Res. 64, 34-44.

Swets, J. A. 1988. Measuring the accuracy of diagnostic systems. Science, 240, 1285-1293.

Saulquin, B., Hamdi, A., Populus, J., Loutier, R., Mangin, A. (In prep.) Estimation of the diffuse attenuation coefficient Kdpar using MERIS satellite reflectances for European coastal waters. ESA Living Planet Symposium. 28 June - 2 July, 2010, Bergen, Norway.

Schaal, G., 2009. Structure et fonctionnement des réseaux trophiques associés aux écosystèmes littoraux rocheux en situations écologiques contrastées. Approches isotopiques et biochimiques combinées. Th. Université Pierre et Marie Curie (UPMC).

Stock, J.D., Montgomery, D.R., Collins, B.D., Dietrich, W.E., Sklar, L., 2005. Field measurements on incision rates following bedrock exposure: implications for process controls on the long profiles of valleys cut by rivers and debris flows. Geological Society of America Bulletin 117, 174-194.

Stefanson, G., 1996. Analysis of groundfish survey abundance data: combining the GLM and delta approaches. ICES Journal of Marine Science 53, 577-588.

Townsend Peterson, A., Papes, M., Soberón, J., 2008. Rethinking receiver operating characteristic analysis applications in ecological niche modeling. Ecological Modelling 213, 63-72

Valero, M.; Destombe, C., Mauger, S., 2011. Using genetic tools for sustainable management of kelps: a literature review and the example of Laminaria digitata. Cah. Biol. Mar. 52, 467-483

Vea, J., Ask, E., 2010. Creating a sustainable commercial harvest of Laminaria hyperborea in Norway. Journal of Apply Phycology 23, 489-494.

Webster, T.L., Murphy, J.B., Gosse, J.C., Spooner, L., 2006. The application of lidar-derived digital elevation model analysis to geological mapping: an example from the Fundy Basin, Nova Scotia, Canada. Can. J. Remote Sensing, 32, 2, 173-193.

Werner, A., Kraan, S., 2004. Review of the potential mechanization of kelp harvesting in Ireland. Marine Environment and Health Series 17. 52p.

Wood, S. N., 2006. Generalized Additive Models: an Introduction with R. Boca Raton: Chapman and Hall-CRC.

Wood, S.N., 2011. Fast stable restricted maximum likelihood and marginal likelihood estimation of semiparametric generalized linear models. Journal of the Royal Statistical Society B 73,1, 3-36. 
1030 Wozencraft, J.M., Lillycrop, W.J., 2003. SHOALS Airborne Coastal Mapping: Past, Present, and Future.

1031 Journal of Coastal Research, special issue 38. Shoreline Mapping and Change Analysis: Technical

1032 Considerations and Management Implications (FALL 2003), 207-215. 
Table 1

Characteristics of remote sensing dataset used to produce a single DTM of the study area

\begin{tabular}{|c|c|c|c|c|}
\cline { 2 - 4 } \multicolumn{1}{c|}{} & Sensors & $\begin{array}{c}\text { Date of survey } \\
\text { acquisition }\end{array}$ & Surface area & Depth range \\
\hline $\begin{array}{c}\text { Airborne Lidar } \\
\text { bathymetry }\end{array}$ & Hawkeye Mk II & $\begin{array}{c}06 / 04 \text { to } 09 / 05 \\
2010\end{array}$ & $170 \mathrm{~km}^{2}$ & $+27 /-32 \mathrm{~m}$ \\
\cline { 5 - 5 } Spectral imagery & Asia Eagle 1k & $170 \mathrm{~km}^{2}$ & $+27 /-10 \mathrm{~m}$ \\
\hline $\begin{array}{c}\text { Mutibeam } \\
\text { echosounder }\end{array}$ & $\begin{array}{c}\text { Simrad EM1000 } \\
100 \mathrm{kHz}\end{array}$ & $05-06 / 2011$ & $97 \mathrm{~km}^{2}$ & $-3 /-97 \mathrm{~m}$ \\
\hline Interferometric & $\begin{array}{c}\text { GeoSwath Plus } \\
250 \mathrm{kHz}\end{array}$ & $\begin{array}{c}09 / 2010 \\
05 / 2011 \\
09 / 2011\end{array}$ & $54 \mathrm{~km}^{2}$ & $+2 /-62 \mathrm{~m}$ \\
sonar bathymetry & \multicolumn{2}{|c}{} &
\end{tabular}

Table 2

Deviance explained by selected variables of the generalized additive models (GAM) used to predict the occurrence probability of $L$. digitata in the Molène Archipelago.

Dist_Sed_Cur: distance to sediment under the influence of current, PInd: bathymetric position index), SST: Sea surface temperature, Q2: $2^{\text {nd }}$ quartile of the year.

\begin{tabular}{llllllll}
\hline & Resid. Df & Resid. Dev & Df & Deviance & Pr(>Chi) & p & \%Exp.Dev \\
\hline $\begin{array}{l}\text { L. digitata Presence/Absence model } \\
\text { (Cross-validation AUC = 0.88) }\end{array}$ & 163 & 224,39 & NA & NA & NA & NA & NA \\
s(Depth) & 159,57 & 178,92 & 3,43 & 45,47 & 0,00 & $p<0.001$ & 20.27 \\
s(Dist_Sed_Cur) & 155,55 & 148,58 & 4,02 & 30,34 & 0,00 & $p<0.001$ & 13.52 \\
s(PInd & 153,65 & 142,71 & 1,91 & 5,87 & 0,05 & $p<0.05$ & 2.61 \\
s(Immersion) & 151,82 & 137,34 & 1,83 & 5,37 & 0,06 & $p<0.1$ & 2.39 \\
s(SST_Q2) & 151,62 & 134,27 & 0,20 & 3,07 & 0,01 & $p<0.05$ & 1.37 \\
te(Depth, PInd) & 148,97 & 105,45 & 2,65 & 28,82 & 0,00 & $p<0.001$ & 12.84 \\
te(Depth, SST_Q2) & 147,41 & 99,79 & 1,56 & 5,66 & 0,04 & $p<0.05$ & 2.52 \\
te(SST_Q2, Immersion) & 141,65 & 54,23 & 5,77 & 45,56 & 0,00 & $p<0.001$ & 20.3 \\
\hline Residuals & NA & NA & NA & 54,23 & NA & NA & 24.17 \\
\hline
\end{tabular}

Table 3

Deviance explained by selected variables of the generalized additive models (GAM) used to predict the biomass of $L$. digitata in the Molène Archipelago.

light_fr_max: Maximum of light fraction, SST: Sea surface temperature, Q3: $3^{\text {d }}$ quartile of the year, exp_wave_M: Wave exposure mean, TSM: Total suspended matter, 02_Wint_M : Winter oxygen mean.

\begin{tabular}{|c|c|c|c|c|c|c|c|}
\hline & Resid. Df & Resid. Dev & Df & Deviance & $\operatorname{Pr}(>\mathrm{Chi})$ & $\mathbf{p}$ & \%Exp.Dev \\
\hline \multicolumn{8}{|l|}{ L. digitata biomass } \\
\hline (Cross-validation CV = 78.11) & 59,00 & 101,04 & NA & NA & NA & NA & NA \\
\hline s(light_fr_max) & 56,47 & 44,84 & 2,53 & 56,20 & 0,00 & $p<0,001$ & 55.62 \\
\hline s(SST_Q3) & 54,62 & 40,03 & 1,85 & 4,81 & 0,03 & $p<0,05$ & 4.76 \\
\hline s(exp_wave_M) & 53,69 & 39,15 & 0,92 & 0,88 & 0,25 & NS & 0.87 \\
\hline $\mathrm{s}(\mathrm{TSM})$ & 52,71 & 39,15 & 0,98 & 0,00 & 0,93 & NS & 0 \\
\hline s(O2_Wint_M) & 51,71 & 39,04 & 1,00 & 0,11 & 0,71 & NS & 0.11 \\
\hline te(light_fr_max, SST_Q3) & 49,37 & 27,71 & 2,35 & 11,33 & 0,00 & $p<0,001$ & 11.21 \\
\hline te(light_fr_max, exp_wave_M) & 46,36 & 19,08 & 3,01 & 8,63 & 0,00 & $\mathrm{p}<0,001$ & 8.54 \\
\hline te(light_fr_max, TSM) & 45,31 & 16,69 & 1,05 & 2,40 & 0,01 & $p<0,05$ & 2.37 \\
\hline Residuals & NA & NA & $\mathrm{NA}$ & 16,69 & NA & NA & 16.51 \\
\hline
\end{tabular}


Table 4

Deviance explained by selected variables of the generalized additive models (GAM) used to predict the occurrence probability of L. hyperborea in the Molène Archipelago.

Dist_Sed_Cur: distance to sediment under the influence of current, SST: Sea surface temperature, Q3: $3^{d}$ quartile of the year., PInd: bathymetric position index

\begin{tabular}{llllllll}
\hline & Resid. Df & Resid. Dev & Df & Deviance & Pr(>Chi) & p & \%Exp.Dev \\
\hline L. hyperborea Presence/Absence model & 208 & 257,5059 & NA & NA & NA & NA & NA \\
(Cross-validation AUC = 0.96) & 204,50 & 170,29 & 3,50 & 87,21 & 0,00 & $p<0,001$ & 33.87 \\
s(Depth) & 200,26 & 101,17 & 4,24 & 69,13 & 0,00 & $p<0,001$ & 26.84 \\
S(dist_Sed_Cur) & 197,70 & 83,45 & 2,57 & 17,72 & 0,00 & $p<0,001$ & 6.88 \\
s(SST_Q3) & 196,64 & 80,25 & 1,06 & 3,21 & 0,08 & $p<0,1$ & 1.25 \\
s(PInd) & 192,15 & 66,99 & 4,49 & 13,26 & 0,01 & $p<0,05$ & 5.15 \\
te(Depth,dist_Sed_Cur) & 191,08 & 54,36 & 1,07 & 12,62 & 0,00 & $p<0,001$ & 4.9 \\
te(Depth, PInd) & NA & NA & NA & 54,36 & NA & NA & 21.11 \\
\hline Residuals & & & & &
\end{tabular}

Table 5 Deviance explained by selected variables of the generalized additive models (GAM) used to predict the biomass of $L$. hyperborea in the Molène Archipelago.

Dep: Depth, SST: Sea surface temperature, Q2 and Q3: $2^{d}$ and $3^{d}$ quartile of the year, Dist_Sed_Cur: distance to sediment under the influence of current, exp_wave_M: Wave exposure mean.

\begin{tabular}{llllllll}
\hline & Resid. Df & Resid. Dev & Df & Deviance & Pr(>Chi) & p & \%Exp.Dev \\
\hline L. hyperborea biomass & 63,00 & 66,10 & NA & NA & NA & NA & NA \\
Cross-validation CV = 57.55 \% & 60,47 & 59,61 & 2,53 & 6,49 & 0,06 & p $<0.1$ & 9.82 \\
s(Depth) & 59,07 & 46,08 & 1,40 & 13,53 & 0,00 & $p<0.001$ & 20.47 \\
s(SST_Q2) & 56,48 & 42,85 & 2,60 & 3,23 & 0,18 & NS & 4.88 \\
s(dist_Sed_Cur) & 55,46 & 42,45 & 1,02 & 0,40 & 0,47 & NS & 0.61 \\
s(SST_Q3) & 53,42 & 41,70 & 2,04 & 0,75 & 0,63 & NS & 1.14 \\
s(exp_wave_M) & 50,05 & 22,39 & 3,38 & 19,31 & 0,00 & p $<0.001$ & 29.21 \\
te(Depth,dist_Sed_Cur) & 47,38 & 14,67 & 2,66 & 7,72 & 0,00 & $p<0.001$ & 11.68 \\
te(Depth, SST_Q3) & 45,57 & 12,66 & 1,82 & 2,01 & 0,02 & $\mathrm{p}<0.05$ & 3.04 \\
te(Depth,exp_wave_M) & NA & NA & NA & 12,66 & NA & NA & 19.15 \\
\hline Residuals & & & & & & &
\end{tabular}

Table 6 Deviance explained by selected variables of the generalized additive models (GAM) used to predict the occurrence probability of $S$. polyschides in the Molène Archipelago Light_fr_max: Maximum of light fraction, dist_Sed_Wav: distance to sediment under the influence of wave, PInd : Bathymetric position index, exp_cur_M: Current exposure mean, Wav_kin_M: Wave kinetic mean.

\begin{tabular}{llllllll}
\hline & Resid. Df & Resid. Dev & Df & Deviance & Pr(>Chi) & p & \%Exp.Dev \\
\hline S. polyschides Presence/Absence model & 206,00 & 224,20 & NA & NA & NA & NA & NA \\
AUC= 0.89 & 202,73 & 178,39 & 3,27 & 45,81 & 0,00 & $p<0.001$ & 20.43 \\
s(light_fr_max) & 198,77 & 140,34 & 3,96 & 38,05 & 0,00 & $p<0.001$ & 16.97 \\
s(dist_Sed_Wav) & 197,68 & 129,00 & 1,09 & 11,34 & 0,00 & $p<0.001$ & 5.06 \\
s(PInd) & 196,58 & 119,24 & 1,10 & 9,77 & 0,00 & $p<0.01$ & 4.36 \\
s(exp_cur_M) & 194,58 & 108,23 & 2,00 & 11,01 & 0,00 & $p<0.01$ & 4.91 \\
s(logWav_kin_M) & NA & NA & NA & 108,23 & NA & NA & 48.27 \\
\hline Residuals & & & & & & &
\end{tabular}




\section{List of figures}

Fig. 1. Study area location. Light grey: intertidal area

Fig. 2. Location map of Lidar and imagery (light grey), acoustic (dark grey) and in situ observation (dots) data acquisitions

Fig. 3. Examples of hard substrate delineation using (a) acoustic, optical image (b) and bathymetric geomorphological derivatives like hillshade, (R: Rock; S: Sediment)

Fig. 4. Statistical modeling process applied in this study for kelp forest mapping

(P/A: Presence/Absence, GAM: Generalized Additive Model, P: Probability of presence, Thp: Probability of presence threshold, Thd: Depth threshold)

Fig. 5. Digital elevation model obtained by (a) kriging at a resolution of $5 \times 5 \mathrm{~m}$ and (b) substrates of the Molène Archipelago area.

Fig. 6. L. digitata prediction maps of (a) occurrence probability (the darker the colour, the most probable, $\max =1$ ), (b) predicted biomass (the darker the colour, the higher the biomass, $\max =30 \mathrm{~kg} \cdot \mathrm{m}-2$ ) , (c) biomass allocation according to bathymetric zones and (d) Recopesca location of harvested areas (dark colored) overlapping hard substrate area (light grey).

Fig. 7. Population size structure (frequency of stipe size classes diagrams) of L. Hyperborea variation according to sediment proximity. Distance to sediment increases from samples 5 and 6 close to sand to samples 1 and 2 away from sand. Reference samples (Ref 1 and 2) are located in rocky area at the same depth as samples close to the sand (5 and 6).

Fig. 8. L. hyperborea prediction maps of occurrence probability (a), biomass (b), biomass allocation according to bathymetric zones (c) and zones for fallow exploitation (d) overlapping hard substrate area (light grey).

Fig. 9. S. polyschides : occurrence probability prediction map

Fig. 10. Distribution of L. polyschides (hatched area) overlapping (a) L. digitata and (b) L. hyperborea (filled areas).

Fig. 11. L. digitata estimated standing stock summed up in gridded $1 \mathrm{~min} \times 1 \mathrm{~min}$ cells overlapping its biomass distribution. Values within grid cells represent the estimated ratio of L. digitata harvested biomass to standing stock.

Fig. 12. Values within grid cells represent the $20 \%$ quota of estimated L. hyperborea standing stock summed up in gridded $1 \mathrm{~min} \times 1$ min cells. Red outlines delimit fallow zones currently used 
Figure 1

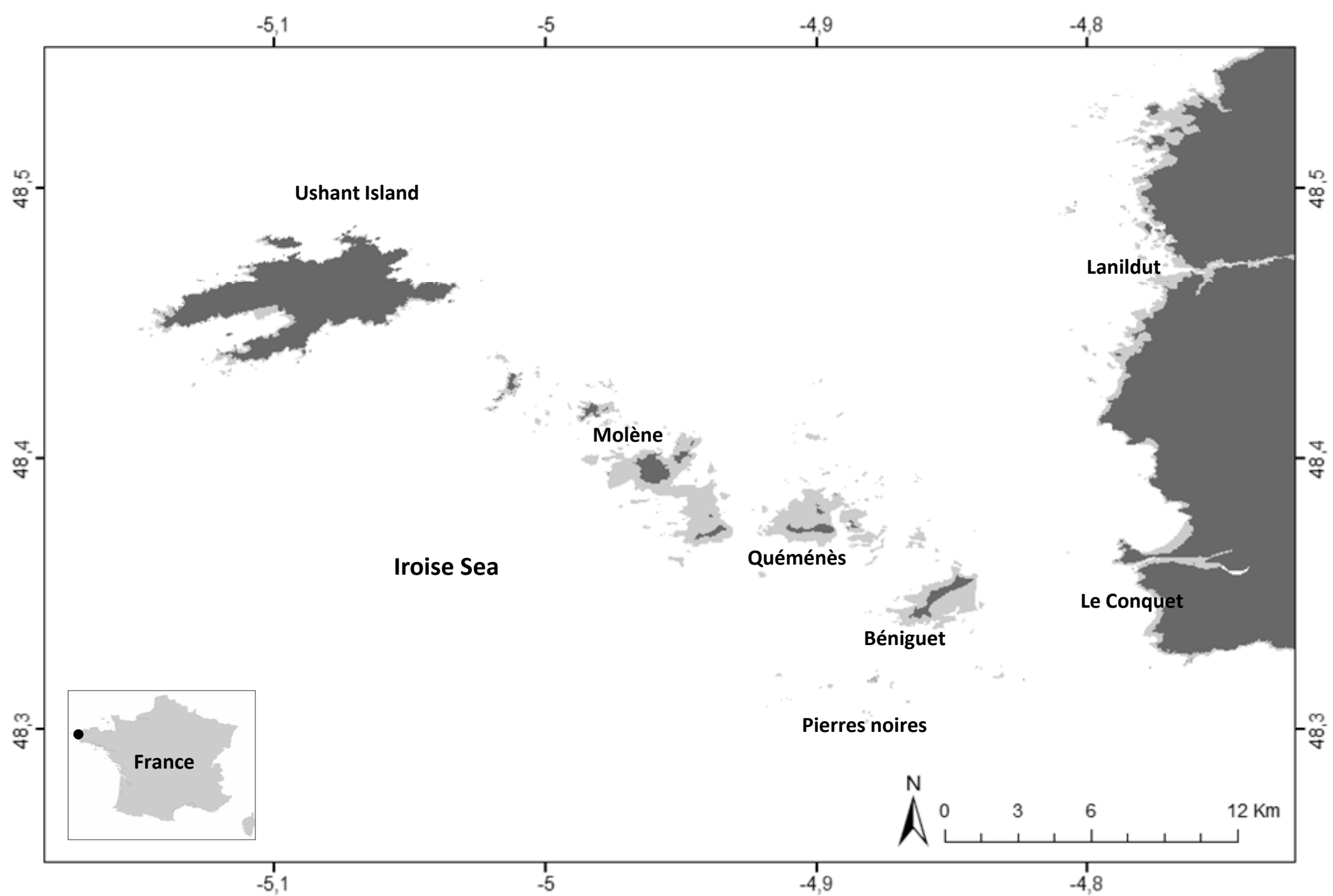


Figure 2

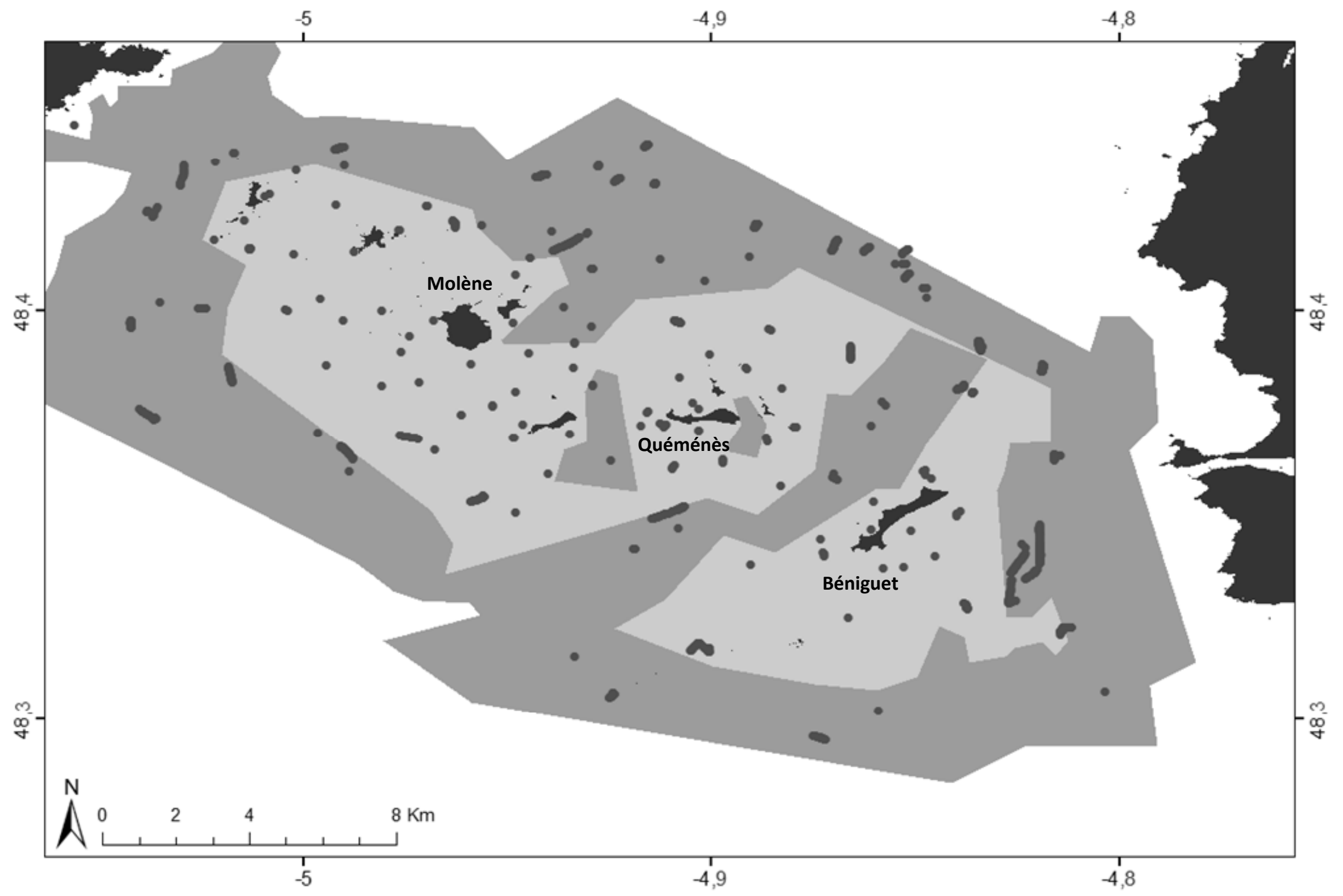


Figure 3

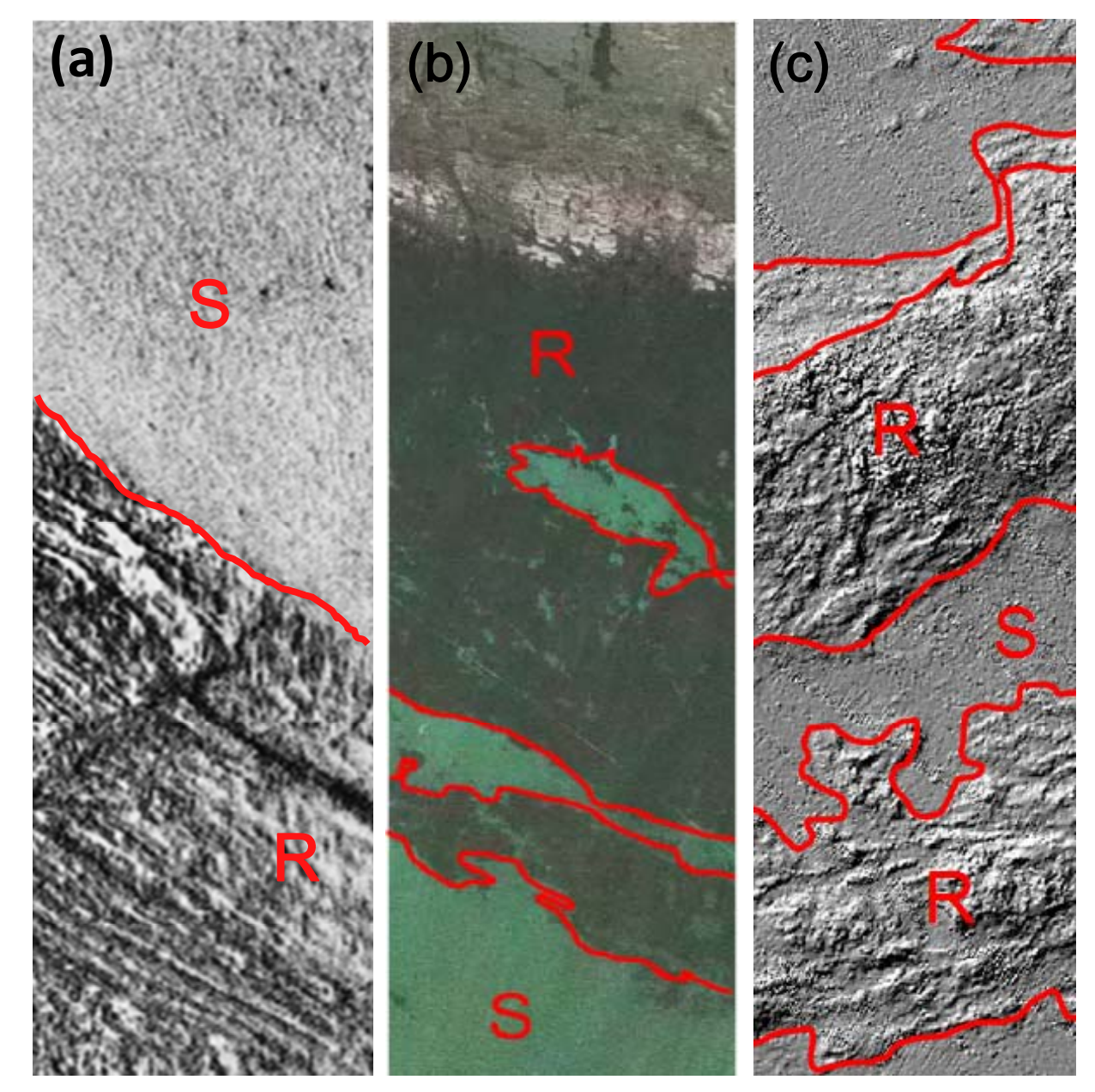




\section{Figure 4}

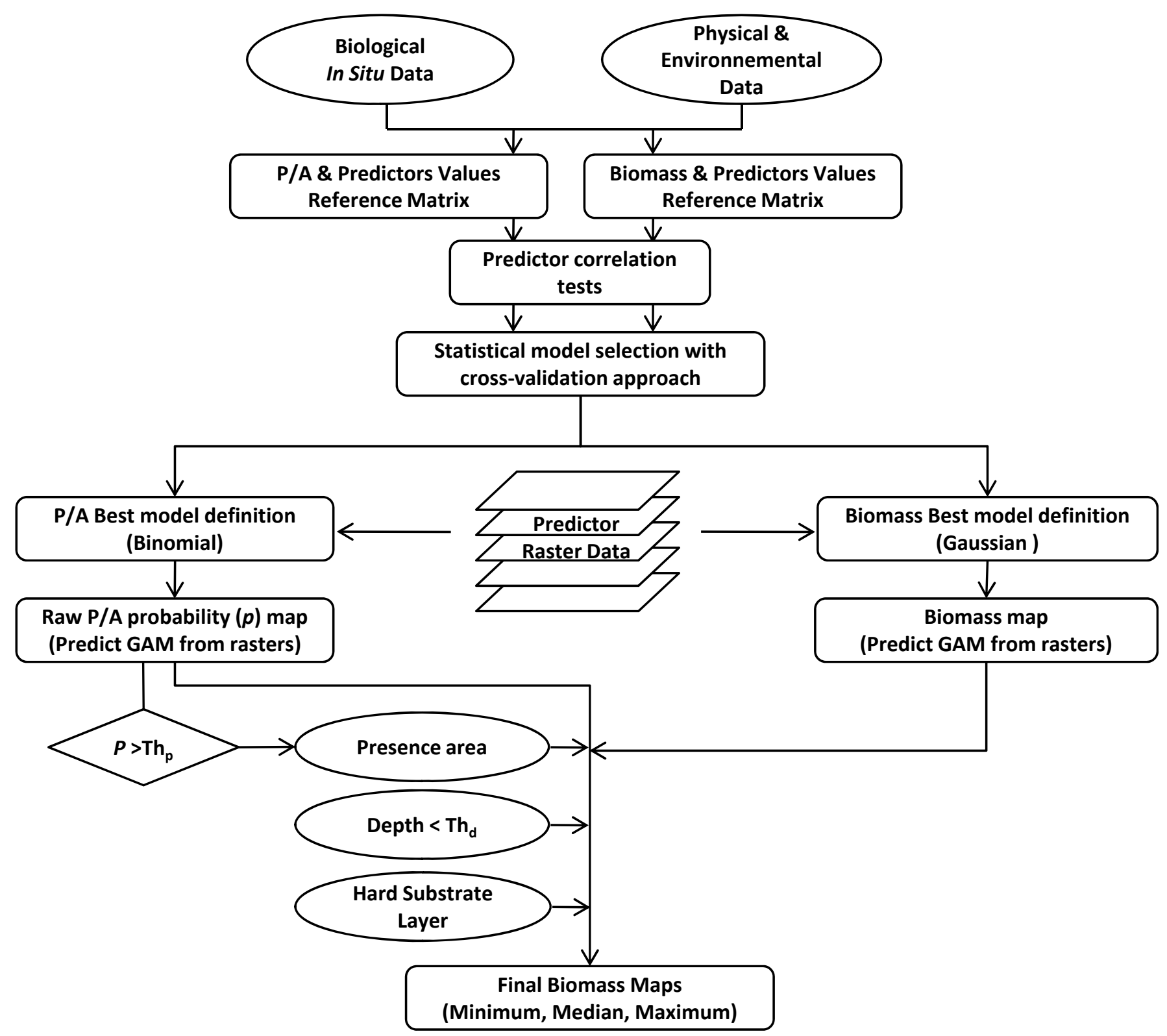


Figure 5
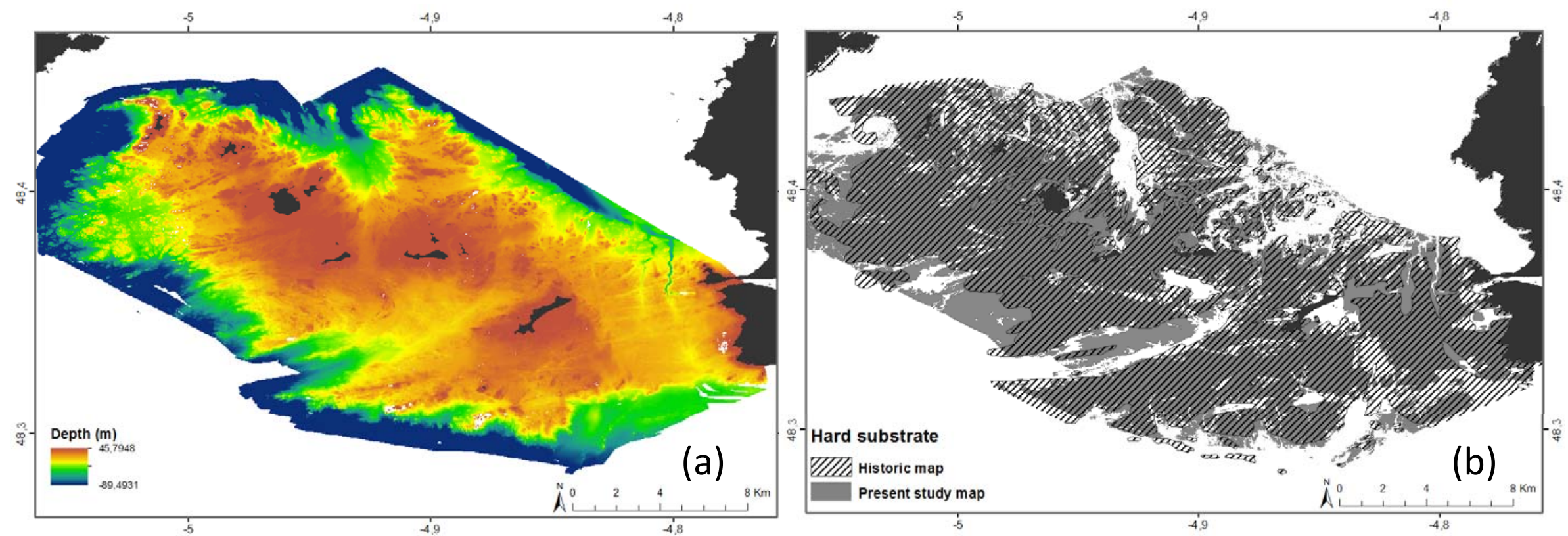
Figure 6
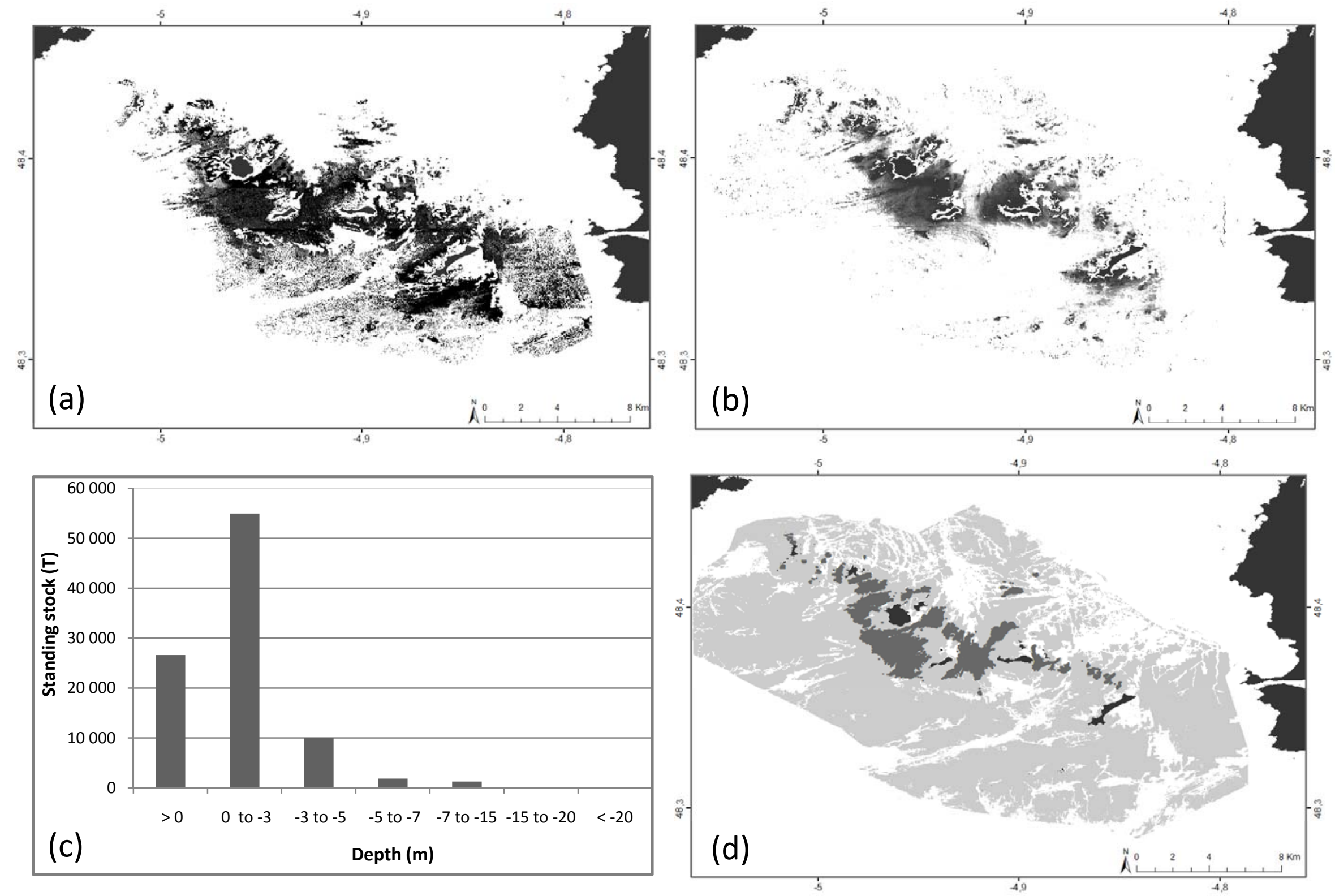


\section{Figure 7}

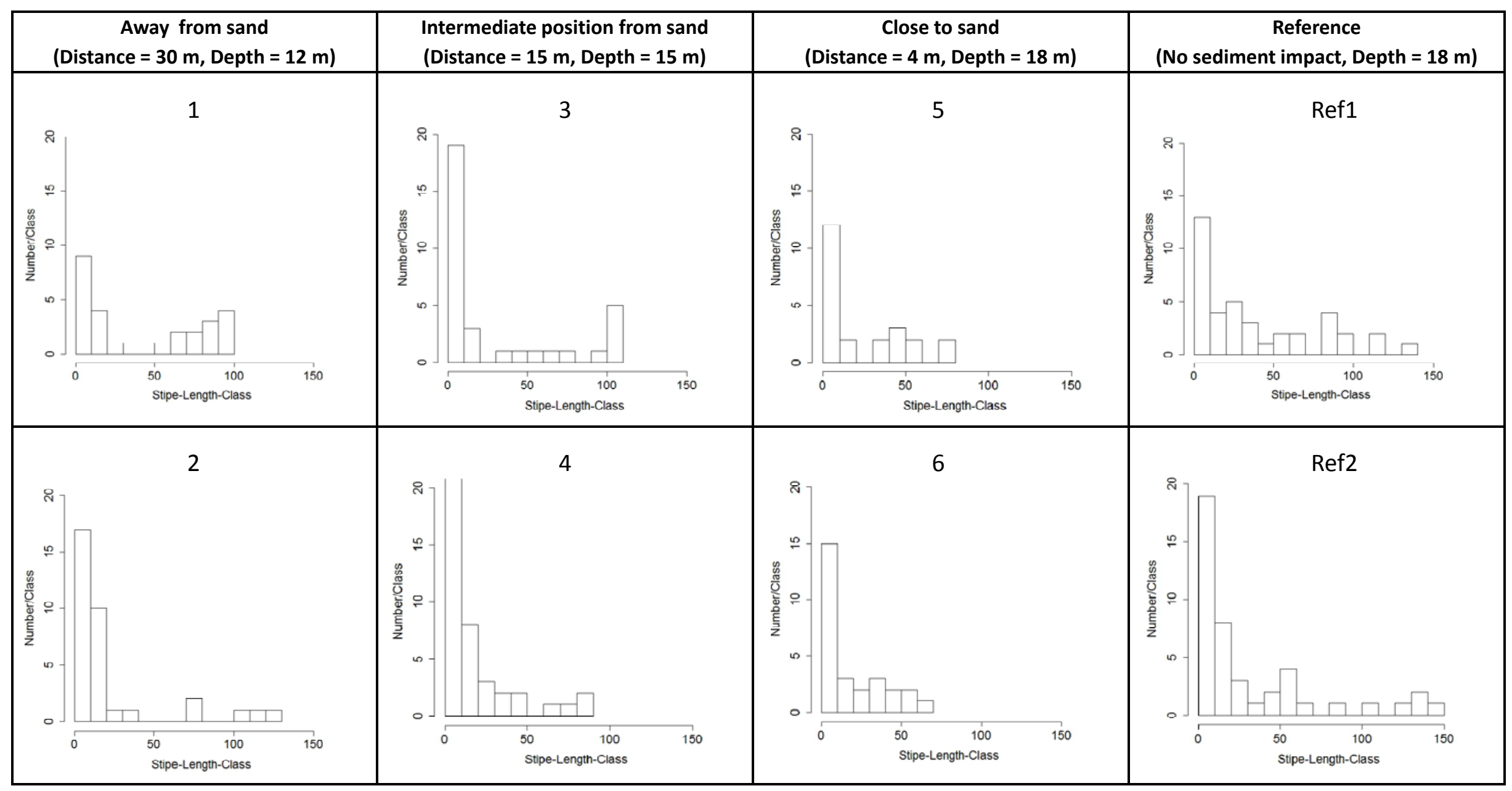


Figure 8
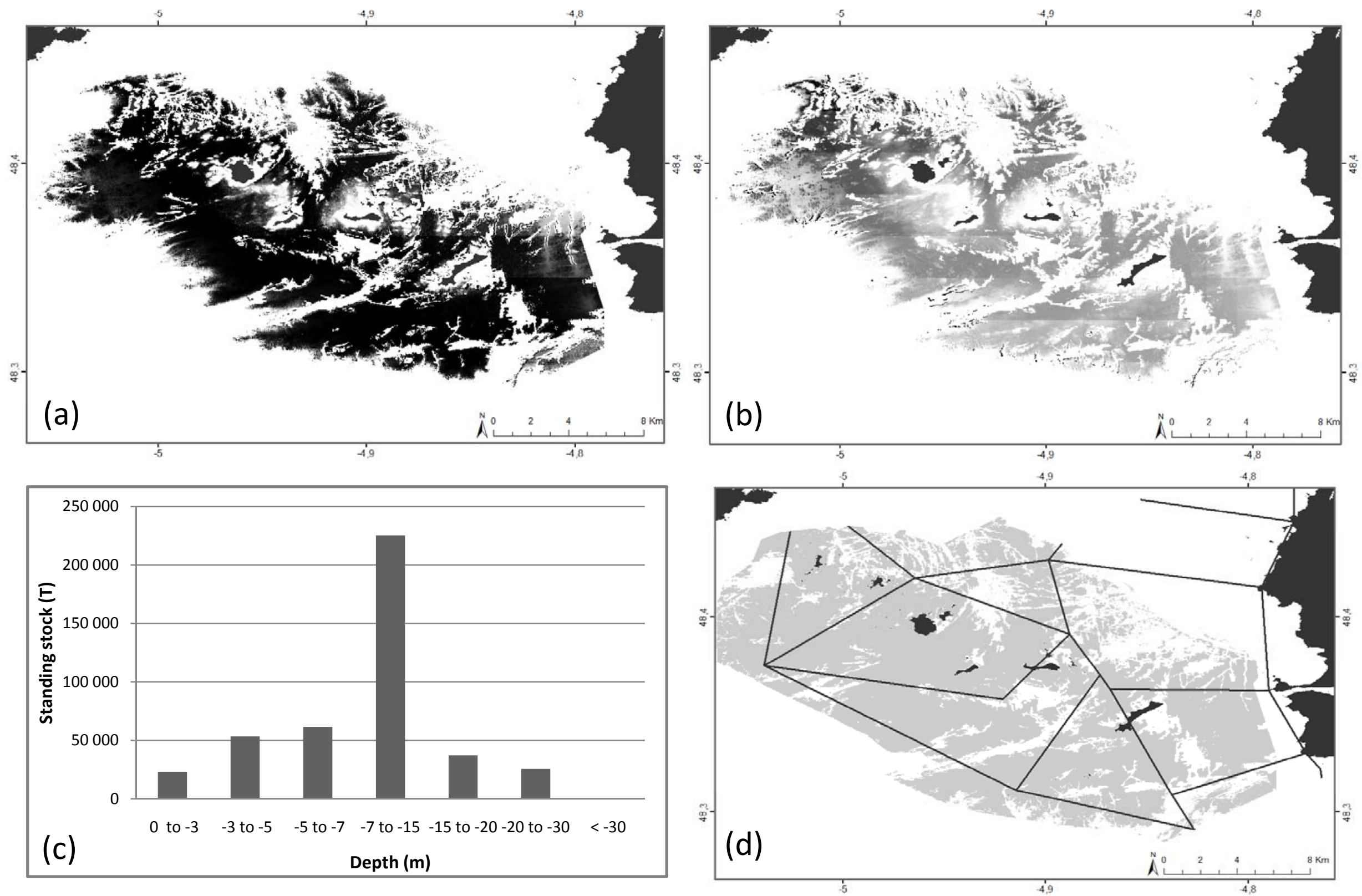
Figure 9

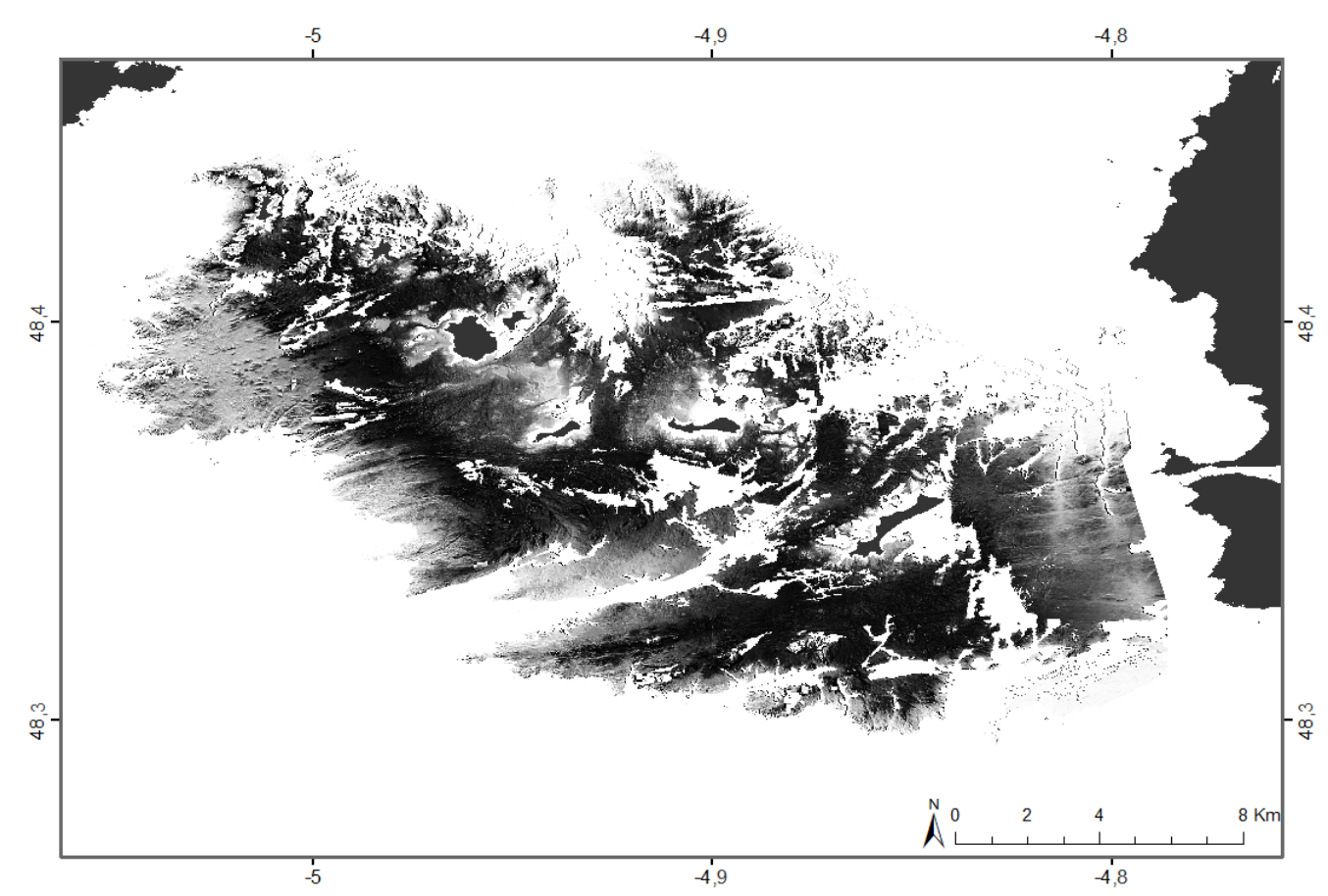


Figure 10
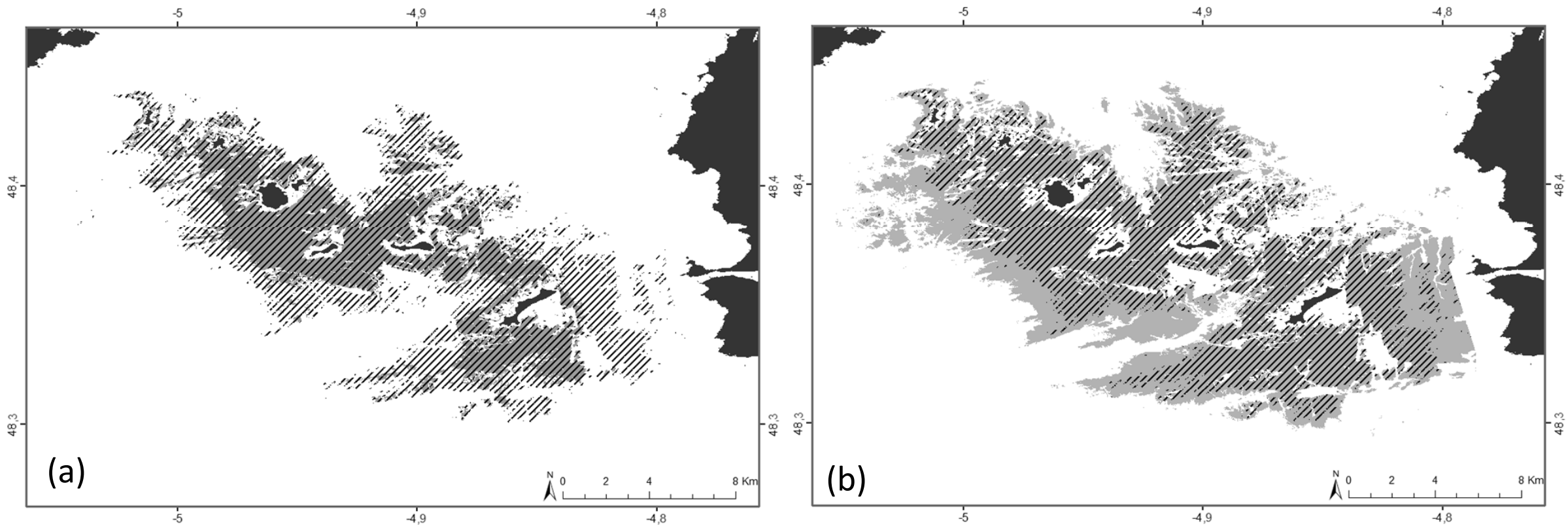
Figure 11

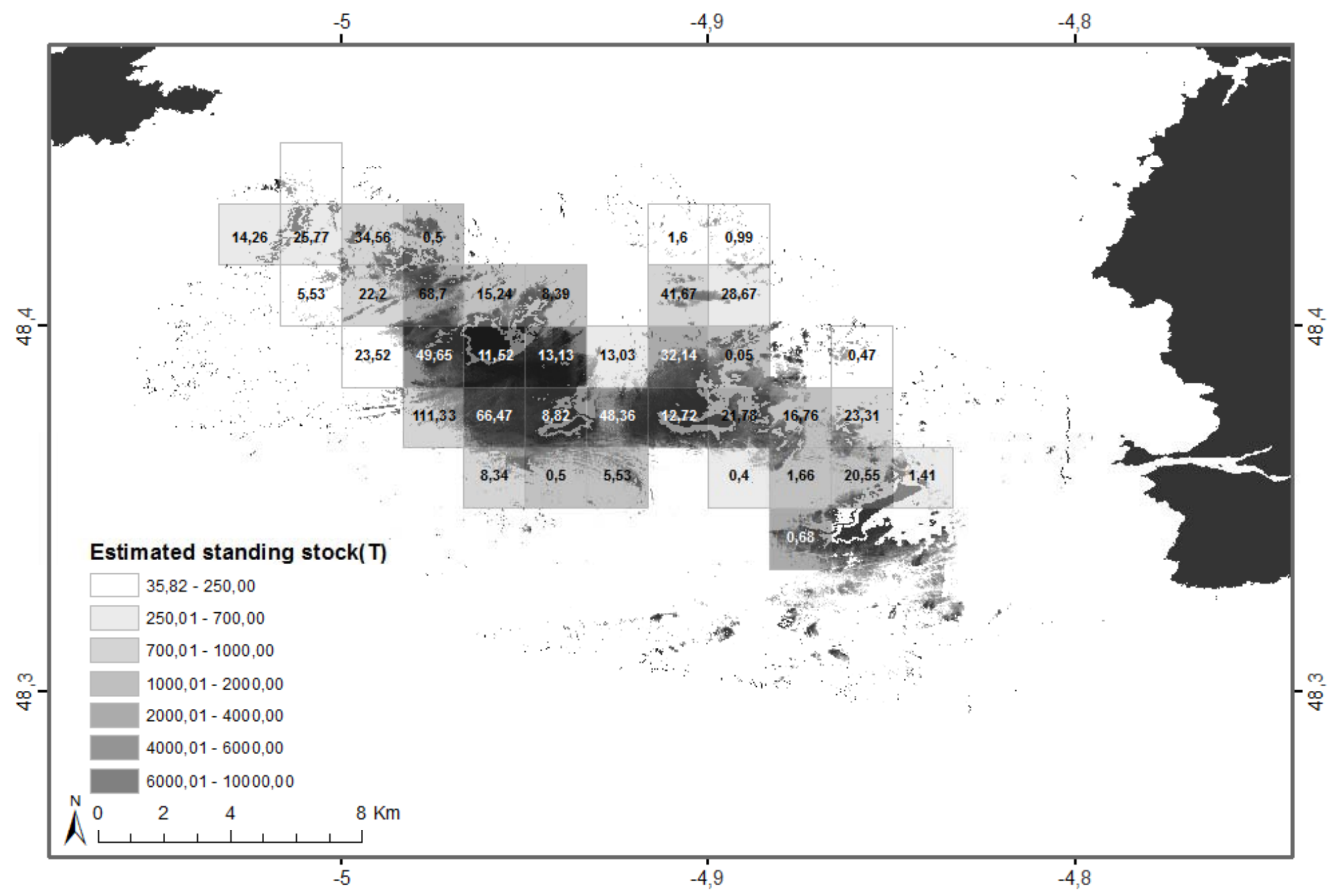


Figure 12

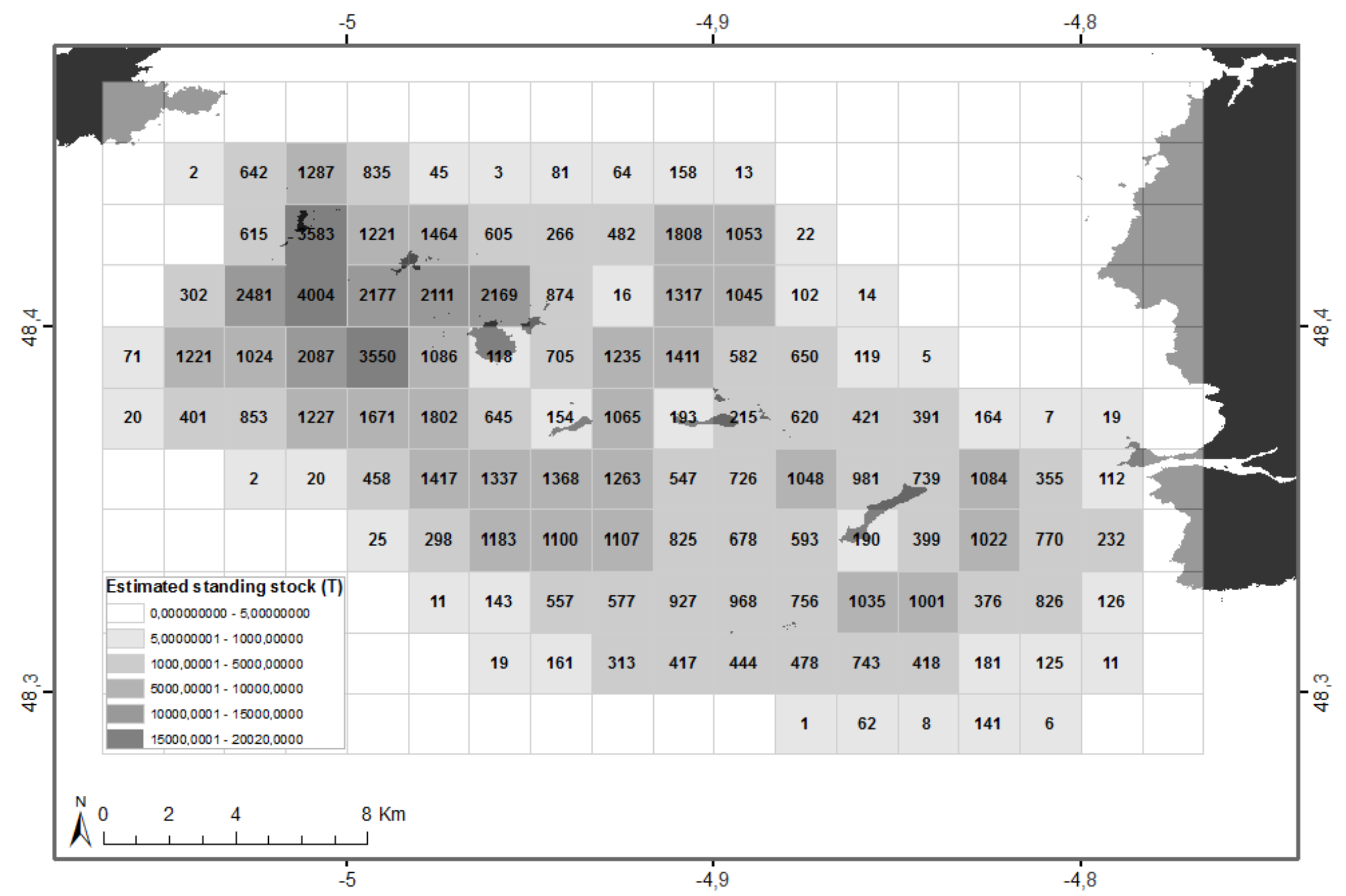

